\title{
Reactive Halogens in the Marine Boundary Layer (RHaMBLe): the tropical North Atlantic experiments
}

\author{
J. D. Lee ${ }^{1,2}$, G. McFiggans ${ }^{3}$, J. D. Allan ${ }^{3,4}$, A. R. Baker ${ }^{5}$, S. M. Ball ${ }^{6}$, A. K. Benton ${ }^{7}$, L. J. Carpenter ${ }^{1}$, R. Commane ${ }^{8}$, \\ B. D. Finley ${ }^{9,}$, M. Evans ${ }^{10}$, E. Fuentes ${ }^{3}$, K. Furneaux ${ }^{*}, \dagger$, A. Goddard ${ }^{8}$, N. Good ${ }^{3}$, J. F. Hamilton ${ }^{1}$, D. E. Heard ${ }^{8,11}$,

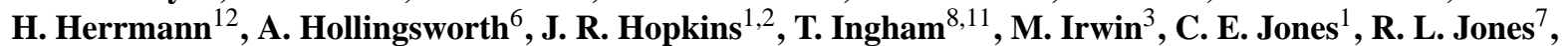 \\ W. C. Keene ${ }^{13}$, M. J. Lawler ${ }^{9}$, S. Lehmann ${ }^{12}$, A. C. Lewis ${ }^{1,2}$, M. S. Long ${ }^{13}$, A. Mahajan ${ }^{8}$, J. Methven ${ }^{14}$, S. J. Moller ${ }^{1}$, \\ K. Müller ${ }^{12}$, T. Müller ${ }^{12}$, N. Niedermeier ${ }^{12}$, S. O'Doherty ${ }^{15}$, H. Oetjen $^{8}$, J. M. C. Plane ${ }^{8}$, A. A. P. Pszenny ${ }^{16,17}$,

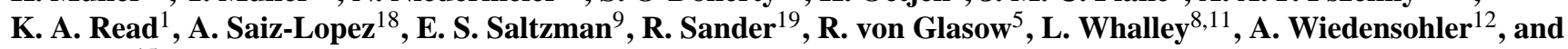 \\ D. Young ${ }^{15}$ \\ ${ }^{1}$ Department of Chemistry, University of York, Heslington, York, YO10 5DD, UK \\ ${ }^{2}$ National Centre for Atmospheric Sciences, University of York, Heslington, York, YO10 5DD, UK \\ ${ }^{3}$ Centre for Atmospheric Sciences, School of Earth, Atmospheric \& Environmental Sciences, University of Manchester, \\ Manchester, M13 9PL, UK \\ ${ }^{4}$ National Centre for Atmospheric Sciences, University of Manchester, Manchester, M13 9PL, UK \\ ${ }^{5}$ School of Environmental Sciences, University of East Anglia, Norwich, NR4 7TJ, UK \\ ${ }^{6}$ Department of Chemistry, University of Leicester, Leicester, LE1 7RH, UK \\ ${ }^{7}$ Department of Chemistry, University of Cambridge, Lensfield Road, Cambridge, CB2 1EW, UK \\ ${ }^{8}$ School of Chemistry, University of Leeds, Leeds, LS2 9JT, UK \\ ${ }^{9}$ School of Physical Sciences, University of California, Irvine, CA 92697, USA \\ ${ }^{10}$ Institute for Atmospheric Science, School of Earth and the Environment, University of Leeds, LS2 9JT, UK \\ ${ }^{11}$ National Centre for Atmospheric Sciences, University of Leeds, Leeds, LS2 9JT, UK \\ ${ }^{12}$ Leibniz Institute for Tropospheric Research, Permoserstraße 15, 04318, Leipzig, Germany \\ ${ }^{13}$ Department of Environmental Sciences, University of Virginia, Charlottesville, VA 22904, USA \\ ${ }^{14}$ Department of Meteorology, University of Reading, P.O. Box 243, Earley Gate, Reading, RG6 6BB, UK \\ ${ }^{15}$ School of Chemistry, University of Bristol, Bristol, BS8 1TS, UK \\ ${ }^{16}$ Institute for the Study of Earth, Oceans, and Space, University of New Hampshire, Durham, NH 03824, USA \\ ${ }^{17}$ Mount Washington Observatory, North Conway, NH 03860, USA \\ ${ }^{18}$ NASA Jet propulsion Laboratory, California Institute of Technology, Pasadena, 91109, USA \\ ${ }^{19}$ Department of Atmospheric Chemistry, Max-Planck Institute of Chemistry, 55020 Mainz, Germany \\ *now at: Program in Science and Technology, Univ. of Washington, Bothell, WA 98011, USA \\ ** formerly at: School of Chemistry, University of Leeds, Leeds, LS2 9JT, UK \\ $\dagger$ sadly passed away, 28 July 2009
}

Received: 16 September 2009 - Published in Atmos. Chem. Phys. Discuss.: 15 October 2009

Revised: 12 January 2010 - Accepted: 22 January 2010 - Published: 1 February 2010

Abstract. The NERC UK SOLAS-funded Reactive Halogens in the Marine Boundary Layer (RHaMBLe) programme comprised three field experiments. This manuscript presents

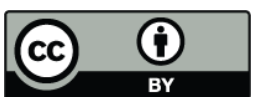

Correspondence to: G. McFiggans (g.mcfiggans@manchester.ac.uk) an overview of the measurements made within the two simultaneous remote experiments conducted in the tropical North Atlantic in May and June 2007. Measurements were made from two mobile and one ground-based platforms. The heavily instrumented cruise D319 on the RRS Discovery from Lisbon, Portugal to São Vicente, Cape Verde and back to Falmouth, UK was used to characterise the spatial distribution

Published by Copernicus Publications on behalf of the European Geosciences Union. 
of boundary layer components likely to play a role in reactive halogen chemistry. Measurements onboard the ARSF Dornier aircraft were used to allow the observations to be interpreted in the context of their vertical distribution and to confirm the interpretation of atmospheric structure in the vicinity of the Cape Verde islands. Long-term ground-based measurements at the Cape Verde Atmospheric Observatory (CVAO) on São Vicente were supplemented by long-term measurements of reactive halogen species and characterisation of additional trace gas and aerosol species during the intensive experimental period.

This paper presents a summary of the measurements made within the RHaMBLe remote experiments and discusses them in their meteorological and chemical context as determined from these three platforms and from additional meteorological analyses. Air always arrived at the CVAO from the North East with a range of air mass origins (European, Atlantic and North American continental). Trace gases were present at stable and fairly low concentrations with the exception of a slight increase in some anthropogenic components in air of North American origin, though $\mathrm{NO}_{\mathrm{x}}$ mixing ratios during this period remained below $20 \mathrm{pptv}$ (note the non-IUPAC adoption in this manuscript of pptv and ppbv, equivalent to $\mathrm{pmol} \mathrm{mol}^{-1}$ and $\mathrm{nmol} \mathrm{mol}{ }^{-1}$ to reflect common practice). Consistency with these air mass classifications is observed in the time series of soluble gas and aerosol composition measurements, with additional identification of periods of slightly elevated dust concentrations consistent with the trajectories passing over the African continent. The CVAO is shown to be broadly representative of the wider North Atlantic marine boundary layer; measurements of $\mathrm{NO}, \mathrm{O}_{3}$ and black carbon from the ship are consistent with a clean Northern Hemisphere marine background. Aerosol composition measurements do not indicate elevated organic material associated with clean marine air. Closer to the African coast, black carbon and NO levels start to increase, indicating greater anthropogenic influence. Lower ozone in this region is possibly associated with the increased levels of measured halocarbons, associated with the nutrient rich waters of the Mauritanian upwelling. Bromide and chloride deficits in coarse mode aerosol at both the CVAO and on D319 and the continuous abundance of inorganic gaseous halogen species at CVAO indicate significant reactive cycling of halogens.

Aircraft measurements of $\mathrm{O}_{3}$ and $\mathrm{CO}$ show that surface measurements are representative of the entire boundary layer in the vicinity both in diurnal variability and absolute levels. Above the inversion layer similar diurnal behaviour in $\mathrm{O}_{3}$ and $\mathrm{CO}$ is observed at lower mixing ratios in the air that had originated from south of Cape Verde, possibly from within the ITCZ. ECMWF calculations on two days indicate very different boundary layer depths and aircraft flights over the ship replicate this, giving confidence in the calculated boundary layer depth.

\section{Introduction}

The recent focus of marine boundary layer halogen research has been on two atmospheric implications: i) participation of reactive halogen species in catalytic ozone destruction cycles including heterogeneous reaction in or on seasalt aerosol and ii) the formation of new aerosol particles in the coastal boundary layer and their potential to act as cloud condensation nuclei $(\mathrm{CCN})$. Largely driven and informed by theoretical modelling investigations (e.g., Vogt et al., 1996; Sander and Crutzen, 1996) firmly based on laboratory kinetic data (e.g., Behnke et al., 1994; Fickert et al., 1999), marine boundary layer (MBL) field measurements have revealed reactive halogen species (RHS) (e.g., Alicke et al., 1999; Allan et al., 2000a; Hebestreit et al., 1999; Saiz-Lopez and Plane, 2004a; Saiz-Lopez et al., 2004b; Peters et al., 2005) as "smoking gun" evidence for activation of unreactive halides from seasalt particles leading to observable changes in aerosol composition (e.g., Ayers et al., 1999; Gabriel et al., 2002; Pszenny et al., 2004; Newberg et al., 2005).

The primary source of reactive inorganic $\mathrm{Cl}$ and $\mathrm{Br}$ in marine air is the production of sea-salt aerosols by waves breaking at the ocean surface (Keene et al., 1999; Sander et al., 2003, respectively) whereas the major sources of reactive I include emission of biogenic iodocarbons from the ocean surface and, in coastal regions, from exposed macroalgae at low tide (Carpenter, 2003); direct emissions of $I_{2}$ from macroalgae (Saiz-Lopez and Plane, 2004a) and from the surface microlayer of the ocean (Garland and Curtis, 1981; Martino et al., 2009) may also be important. In most regions, the marine aerosol is rapidly acidified (primarily by $\mathrm{HNO}_{3}$ ) resulting in dechlorination via $\mathrm{HCl}$ volatilisation. Some $\mathrm{HCl}$ reacts subsequently with $\mathrm{OH}$ to produce atomic $\mathrm{Cl}$. The photolysis of iodocarbons and $\mathrm{I}_{2}$ produces atomic I. Halogen atoms react with ozone to yield halogen oxides (XO), which themselves react with $\mathrm{HO}_{2}$ and $\mathrm{NO}_{2}$ to yield intermediate species, $\mathrm{HOX}$ and $\mathrm{XONO}_{2}$, which further react at surfaces of acidic aerosols to yield aqueous HOX. In the presence of $\mathrm{H}^{+}$, dissolved HOX reacts with available halide ions $\left(\mathrm{Y}^{-}\right)$ to form interhalogen species $\mathrm{XY}$ including $(\mathrm{IBr}, \mathrm{ICl}, \mathrm{BrCl}$, $\mathrm{Br}_{2}$ and $\mathrm{Cl}_{2}$ ), which subsequently volatilise and photolyse to yield two halogen atoms. This process leads to significant, widespread depletion of $\mathrm{Br}^{-}$relative to fresh sea salt (Sander et al., 2003) and is responsible for the associated production of reactive halogens from the pool of halide ions produced in association with sea-salt aerosols.

There is significant chloride concentration in fresh seawater, roughly 660 times less bromide and comparatively trace levels of iodide. This, and the relative aqueous reaction rates of $\mathrm{HOX}$ with $\mathrm{Br}^{-}$and $\mathrm{Cl}^{-}$, results in the seasalt aerosol being a significant source of reactive chlorine and bromine, but a much weaker source of iodine. This implies that seasalt will provide a sink rather than a source of iodine and requires that gaseous sources of organohalogen (Carpenter et al., 1999, 2000) or other photolabile iodine-containing species are the 
precursors to reactive iodine. The IO self-reaction and the reaction of $\mathrm{IO}$ with $\mathrm{BrO}$ both lead to formation of iodine dioxide (OIO), the uptake which may be the source of significant observed iodine enrichment in aerosol relative to seawater. Vogt et al. (1999) first incorporated iodine chemistry into halogen activation mechanisms. The emission of biogenic photolabile iodine and initiation of, and/or coupling to, the recycling of RHS through seasalt aerosol has been investigated through various observationally-informed modelling studies coupling gaseous photochemistry, aerosol microphysics and chemistry on various scales and at various levels of simplification (Stutz et al., 1999; McFiggans et al., 2000, 2002; Toyota et al., 2001; von Glasow et al., 2002a,b, 2004; Lowe et al., 2009). Such studies have revealed significant potential impact of marine halogens on ozone, $\mathrm{NO}_{\mathrm{x}}$ and $\mathrm{HO}_{\mathrm{x}}$ ratios and aerosol halide concentrations and of DMS oxidation by $\mathrm{BrO}$ and non-methane hydrocarbon (NMHC) oxidation by $\mathrm{Cl}$ atoms. Reviews of MBL halogen chemistry have been compiled by Carpenter (2003); Sander et al. (2003) and von Glasow and Crutzen (2007). This manuscript is concerned with the context for halogen investigations in the remote MBL; coastal halogen processes and impacts will be addressed in the companion paper of McFiggans et al. (2009). Whilst a complete characterisation of halogen chemistry and quantification of its impacts on oxidation processes requires detailed model studies, many aspects of halogen cycling are accessible to interpretation by direct measurements of RHS, their precursors and other trace gases. For example, clear evidence of significant local perturbations to radical chemistry partially attributable to the participation of halogens (Bloss et al., 2005) was identified in the coastal MBL by combining measurements of $\mathrm{XO}$ with those of $\mathrm{OH}$ and $\mathrm{HO}_{2}$. A key goal of the experiments reported here was to establish whether such signals of $\mathrm{XO}$ impacts are also present in the remote MBL. The perturbations to oxidative chemistry due to remote MBL halogen chemistry affecting $\mathrm{OH}$ concentrations (due to $\mathrm{XO}+\mathrm{HO} \rightarrow \mathrm{HOX}+\mathrm{O}_{2} \rightarrow \mathrm{OH}+\mathrm{X}$ or reductions in the $\mathrm{O}_{3}$ concentration resulting from catalytic cycles) may present significant climate implications by increasing the methane lifetime in the tropical MBL ( $40 \%$ of $\mathrm{CH}_{4}$ loss to $\mathrm{OH}$ attack occurs within the tropical boundary layer (Lawrence et al., 2001 ); over $80 \%$ of this within the tropical MBL) or by enhancing the oxidation of dimethylsulphide, thereby impacting on cloud condensation nucleus formation and transformation. Of course, the impacts are likely to be complex (for example, the impacts of enhanced $\mathrm{Cl}$ concentration on $\mathrm{CH}_{4}$ loss will tend to decrease its lifetime), though nonetheless important to resolve.

The Reactive Halogens in the Marine Boundary Layer (RHaMBLe) programme was conceived to enhance the capability of predicting the impacts of both remote and coastal halogen cycling by provision of improved process descriptions and of quality assured data for evaluation of modelling efforts. This overview is concerned with the remote MBL studies, which focused on the roles of halogens in oxidative processes and on the associated aerosol transformations resulting from RHS cycling. Two open ocean deployments within RHaMBLe were designed to link with long-term studies in the tropical Atlantic Ocean at the Cape Verde Atmospheric Observatory (CVAO) on São Vicente (Read et al., 2008, 2009; Lee et al., 2009) off the west coast of Africa $\left(16.848^{\circ} \mathrm{N}, 24.871^{\circ} \mathrm{W}\right)$. The tropical Atlantic atmosphere, in addition to being representative of remote ocean environments, is of specific major importance for the Earth's climate, ecology and biogeochemistry, yet is poorly characterised; large radiative fluxes and high water vapour concentrations lead to a high oxidative turnover. In addition, significant concentrations of reactive bromine have been observed in the tropical northeast Atlantic (Leser et al., 2003; Quack et al., 2004; Keene et al., 2009). Available evidence suggests that the primary source for reactive $\mathrm{Br}$ in this region is the production of sea salt aerosol and its subsequent acid-catalysed autocatalytic activation. Emission of photolysable bromocarbons from the surface ocean from the large upwelling area off Mauritania and transport of reactive $\mathrm{Br}$ from continents may also contribute. During late spring and summer, the region near CV is typically influenced by "clean" North Atlantic marine air along the NNE trade winds, allowing study of background Atlantic air, expected to be frequently influenced by the Mauritanian upwelling and associated oceanic gases. During autumn and winter, CV is situated in the direct transport pathway of westerly dust and biomass burning plumes from Africa to the North Atlantic.

Figure 1 shows the probability of an airmass having passed over a region $5 \mathrm{~d}$ before arrival at CVAO for June-August 2000 and for the whole of 2000, using ECMWF data. Warm colours represent higher probability. The projects were scheduled for early summer to maximise the frequency of airmass trajectories passing over the Mauritanian upwelling region prior to arrival at the CVAO, increasing the potential role of halogen chemistry; and minimise the dust input from Saharan outflow which dominates other periods and may significantly affect heterogeneous processes and perturb the radiative balance and hence photochemistry. At higher altitude, there may be significant dust outflows but MBL chemistry is less likely to be directly affected.

The aims of the RHaMBLe remote marine measurement investigations were to provide a comprehensive characterisation of halogen compounds in the remote marine atmosphere, including both organic and inorganic reactive species and providing substantial spatial and temporal coverage. The first experiment comprised an intensive campaign and supplementation of the long-term continuous measurements at CVAO. The second deployment comprised a simultaneous ship transect through the biologically-active upwelling region west of Mauritania aiming to investigate the regional contribution and spatial variability of biogenically derived sea-air flux of precursors to RHS sources. During this second deployment, an instrumented aircraft was deployed to investigate vertical variability. This manuscript presents the 

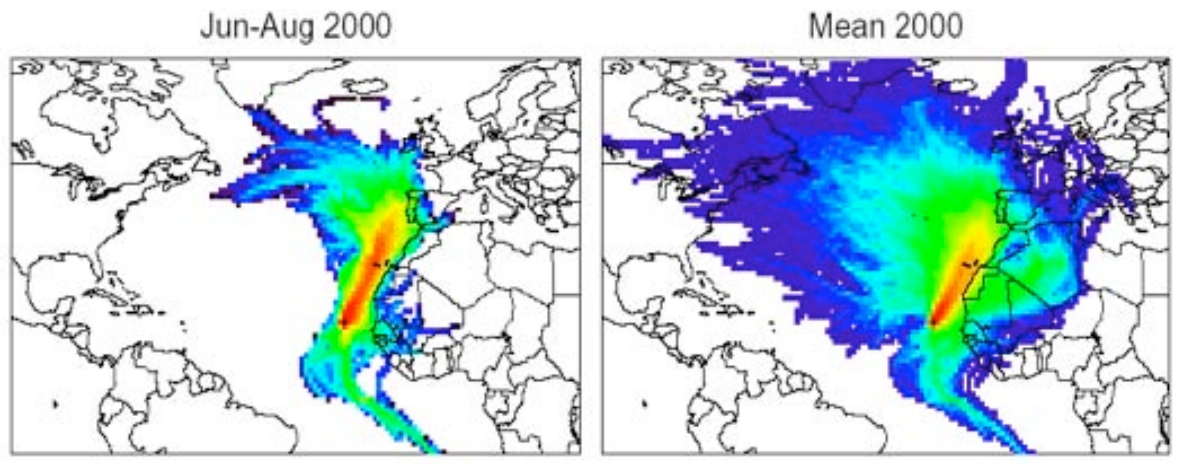

Fig. 1. The probability density of an airmass having passed over a region 5 days before arrival at CVAO for June-August 2000 and for the whole of 2000, using ECMWF data. Warm colours represent higher probability.

scientific rationale and the meteorological and other conditions providing the context for the RHaMBLe remote marine experiments.

\section{Experimental methods}

\subsection{Enhanced long-term characterisation and intensive detailed study of remote MBL halogen chemistry}

Few RHS measurements exist in the remote marine atmosphere (Allan et al., 2000a, 2001; Saiz-Lopez et al., 2004b). No long-term measurements of inorganic RHS had been made at a single location in this environment prior to the RHaMBLe project; therefore variability in RHS is highly uncertain. The remote studies within the RHaMBLe project at the CVAO comprised two components: i) a heavily instrumented intensive project and ii) supplementation of the ongoing long-term measurements with measurements of XO species to determine their variability over an annual cycle. The measurements were designed to enable direct estimation of the roles of oceanic halogen emissions in MBL chemistry through detailed characterisation of $\mathrm{IO}, \mathrm{BrO}, \mathrm{OH}, \mathrm{HO}_{2}$ and $\mathrm{NO}_{3}$ and estimation of the effects of marine halogens. These measurements may be used to investigate the impacts of halogens on lifetime predictions of reduced sulphur species and greenhouse gases, and on the MBL $\mathrm{O}_{3}$ budget. In addition to the gaseous species, broad characterisation of physical and chemical aerosol properties were made; both to describe the medium for halogen activation and for quantifying the potential sink for radical species, which are thought to play an important role (Haggerstone et al., 2005) in the radical budget. The aims of the CVAO RHaMBLe activities were therefore to provide a detailed characterisation of reactive halogen cycling in the tropical marine boundary layer and their impact on marine oxidation through in situ intensive measurements of all major participating species and to provide enhanced long-term capability for RHS measurement.

\subsubsection{Technique descriptions}

Table 1 provides a listing of the instrumentation deployed at CVAO during the intensive and long-term RHaMBLe participation.

Long-term measurements at the CVAO commenced in summer 2006 and continued for the duration of the RHaMBLe project. Located on a beach that faces the strong $\mathrm{NE}$ trade winds and is free of any significant coastal features that could affect boundary layer chemistry, CVAO was sited to receive air masses well processed within the marine troposphere, with very rare pollution from local activities. The observatory site comprises several instrumented shipping containers, located on flat ground about $30 \mathrm{~m}$ back from the sea edge, $10 \mathrm{~m}$ a.s.l. and two sampling towers; one $10 \mathrm{~m}$ and one $30 \mathrm{~m}$ high. $\mathrm{O}_{3}$ and $\mathrm{NO}_{\mathrm{x}}$ were measured from $5 \mathrm{~m}$ above ground level ( $15 \mathrm{~m}$ a.s.l.). $\mathrm{O}_{3}$ was measured using a UV absorption analyser (TEI 49i), with data taken at 1 min frequency. Measurements of $\mathrm{NO}_{\mathrm{x}}$ were made using a single channel, chemiluminescence NO detector with a photolytic $\mathrm{NO}_{2}$ converter (diode based blue light converter (BLC) Droplet Measurement Technologies). The instrument (Air Quality Design Inc, US) has an air sample flow through the $\mathrm{NO}_{\mathrm{x}}$ converter, with the $\mathrm{NO}$ measurement taken when the $\mathrm{NO}_{2}$ converter diodes are periodically switched off. The sample flow is produced from the main vacuum pump, which holds the pressure of the main reaction chamber at $\sim 10 \mathrm{mbar}$. Calibration of $\mathrm{NO}$ and $\mathrm{NO}_{2}$ was carried out at successive $13 \mathrm{~h}$ intervals by adding a small flow of NO calibration gas to the sample flow from a cylinder (BOC Gases, UK). This allowed calculation of sensitivities in the same air humidity as ambient. A UV photolysis lamp was used to produce ozone in the calibration air to perform gas phase titration of the NO to $\mathrm{NO}_{2}$ for calibration of the $\mathrm{NO}_{2}$ conversion efficiency of the BLC. The instrument performed at detection limits (DL) of 1.5 and 4 pptv for hourly averaged $\mathrm{NO}$, and $\mathrm{NO}_{2}$, respectively. A full description of the long term measurements of $\mathrm{O}_{3}$ and $\mathrm{NO}_{\mathrm{x}}$ can be found in Lee et al. (2009). 
Table 1. Measurement and instrument listing for the RHaMBLe CVAO experiment in May-June 2007.

\begin{tabular}{|c|c|c|c|c|}
\hline Target species & Instrument & Technique & DL (integration time) & Reference \\
\hline \multicolumn{5}{|l|}{$\begin{array}{l}\text { Long-term } \\
\text { measurements }\end{array}$} \\
\hline $\mathrm{O}_{3}$ & $\begin{array}{l}\text { TEI } 49 \mathrm{i} \\
\text { (CVAO core) }\end{array}$ & UV absorption & $1 \mathrm{ppbv}(60 \mathrm{~s})$ & Lee et al. (2009) \\
\hline NO & $\begin{array}{l}\mathrm{NO}_{\mathrm{xy}} \\
\text { (CVAO core) }\end{array}$ & Chemiluminescence & $1.5 \mathrm{pptv}(1 \mathrm{~h})$ & Lee et al. (2009) \\
\hline $\mathrm{NO}_{2}$ & $\begin{array}{l}\mathrm{NO}_{\mathrm{xy}} \\
\text { (CVAO core) }\end{array}$ & $\begin{array}{l}\text { Photolytic conversion } \\
\rightarrow \text { Chemiluminescence }\end{array}$ & 5 pptv (1 h) & Lee et al. (2009) \\
\hline$\Sigma \mathrm{NO}_{\mathrm{y}}$ & $\begin{array}{l}\mathrm{NO}_{\mathrm{xy}} \\
\text { (CVAO core })\end{array}$ & $\begin{array}{l}\text { Molybdenum catalysis } \\
\rightarrow \text { Chemiluminescence }\end{array}$ & 4 pptv $(1 \mathrm{~h})$ & Lee et al. (2009) \\
\hline $\mathrm{CO}$ & $\begin{array}{l}\text { TEI } 43 \\
\text { (U. York) }\end{array}$ & UV Fluorescence & $2 \mathrm{ppbv}(1 \mathrm{~min})$ & Read et al. (2009) \\
\hline DMS, oVOCs, VOCs & $\begin{array}{l}\text { GC/FID } \\
\text { (CVAO core) }\end{array}$ & $\begin{array}{l}\text { Gas chromatography } \\
\text { Flame Ionisation Detector }\end{array}$ & $1 \mathrm{pptv}(1 \mathrm{~h})$ & Read et al. (2009) \\
\hline $\begin{array}{l}\text { Halocarbons, } \\
\mathrm{C}_{\mathrm{x}} \mathrm{H}_{\mathrm{y}} \mathrm{X}_{\mathrm{z}}\end{array}$ & $\begin{array}{l}\text { GC/MS } \\
\text { (CVAO core) }\end{array}$ & $\begin{array}{l}\text { Gas chromatography } \\
\text { Mass Spectrometry }\end{array}$ & $0.05 \mathrm{pptv}(30 \mathrm{~min})$ & Simmonds et al. (2004) \\
\hline $\mathrm{IO}, \mathrm{BrO}, \mathrm{I}_{2}, \mathrm{OIO}$ & $\begin{array}{l}\text { Long-path DOAS } \\
\text { (U. Leeds) }\end{array}$ & $\begin{array}{l}12 \mathrm{~km} \text { path } \\
\text { Xe arc lamp active DOAS }\end{array}$ & $\begin{array}{l}0.9,0.5,5,2 \mathrm{pptv} \\
(20 \mathrm{~min})\end{array}$ & Plane and Saiz-Lopez (2006) \\
\hline $\begin{array}{l}\mathrm{CH}_{4}, \mathrm{CO}_{2}, \mathrm{~N}_{2} \mathrm{O} \\
\mathrm{CO}\end{array}$ & $\begin{array}{l}\text { Flask Sampling } \\
\text { (MPI Jena) }\end{array}$ & Whole air GC/FID & $\begin{array}{l}0.7,30,0.3 \\
1.4 \mathrm{ppbv}\end{array}$ & Kozlova and Manning (2009) \\
\hline $\begin{array}{l}\text { Aerosol, } \mathrm{PM}_{10} \\
\mathrm{Mg}^{2+}, \mathrm{Ca}^{2+}, \mathrm{NH}_{4}^{+}\end{array}$ & $\begin{array}{l}\text { Hi-Vol filter, Metrohm } \\
761\end{array}$ & Ion Chromatography & $\begin{array}{l}1,1,1,2,2,1 \\
5,8,9,3 \mathrm{ng} \mathrm{m}^{-3}\end{array}$ & \\
\hline $\begin{array}{l}\mathrm{Na}^{+}, \mathrm{K}^{+}, \mathrm{Br}^{-}, \mathrm{Cl}^{-} \\
\mathrm{NO}_{3}^{-}, \mathrm{SO}_{4}^{2-} \text {, oxalate }\end{array}$ & (IfT, Leipzig) & & & Müller et al. (2009a) \\
\hline $\mathrm{OC}, \mathrm{EC}$ & C-mat 5500 & NDIR & $0.3,0.1 \mu \mathrm{g} \mathrm{m}^{-3}$ & Herrmann et al. (2006) \\
\hline $\begin{array}{l}\text { Particle number } \\
\text { size distributions }\end{array}$ & $\begin{array}{l}\text { SMPS } \\
\text { APS }\end{array}$ & $\begin{array}{l}\text { Scanning mobility sizing } \\
\text { Aerodynamic sizing }\end{array}$ & $\begin{array}{l}4.5 \mathrm{~min} \\
4.5 \mathrm{~min}\end{array}$ & Birmili et al. (1999) \\
\hline $\begin{array}{l}\text { Spectral absorption } \\
\text { coefficients }\end{array}$ & SOAP & $\begin{array}{l}\text { Filter-based absorption } \\
\text { photometry }\end{array}$ & $0.5 \mathrm{Mm}^{-1}(30 \mathrm{~min})$ & Müller et al. (2009b) \\
\hline \multicolumn{5}{|l|}{$\begin{array}{l}\text { RHaMBLe intensive } \\
\text { measurements }\end{array}$} \\
\hline $\mathrm{OH}, \mathrm{HO}_{2}$ & $\begin{array}{l}\text { FAGE LIF } \\
\text { (U. Leeds) }\end{array}$ & $\begin{array}{l}\text { Laser induced } \\
\text { fluorescence at } 508 \mathrm{~nm}\end{array}$ & $0.02,0.1 \mathrm{pptv}(1 \mathrm{~min})$ & Whalley et al. (2009) \\
\hline$j \mathrm{O}\left({ }^{1} \mathrm{D}\right)$ & $\begin{array}{l}\text { Filter radiometer } \\
\text { (U. Leeds) }\end{array}$ & $\lambda$-filtered photon flux & N/A & Whalley et al. (2009) \\
\hline $\mathrm{Cl}_{2}$ & $\begin{array}{l}\text { Triple-Quadrupole } \\
\text { CIMS (U.C. Irvine) }\end{array}$ & $\begin{array}{l}\text { Chemical Ionisation } \\
\text { Mass Spectrometry }\end{array}$ & 1.9 pptv $(1 \mathrm{~h})$ & Finley and Saltzman (2008) \\
\hline $\begin{array}{l}\mathrm{Cl}^{*}, \mathrm{HCl}, \mathrm{HNO}_{3}, \mathrm{NH}_{3}, \\
\mathrm{HCOOH}, \mathrm{CH}_{3} \mathrm{COOH}\end{array}$ & $\begin{array}{l}\text { Tandem mist chamber } \\
\text { (U. Virginia } \\
\text { \& U. New Hampshire) }\end{array}$ & Ion chromatography & $\begin{array}{l}14,26,12,3,29,44 \\
\operatorname{pptv}(2 \mathrm{~h})\end{array}$ & Keene et al. (2007) \\
\hline $\begin{array}{l}\mathrm{Br}, \mathrm{I}, \mathrm{Na}, \mathrm{Al}, \mathrm{Mn} \& \mathrm{~V} \\
\text { in bulk aerosol }\end{array}$ & $\begin{array}{l}\text { Filter pack } \\
\text { (U. New Hampshire }\end{array}$ & Neutron activation & $\begin{array}{l}2.2,0.94,0.53,0.022 \\
0.25,0.55 \mathrm{ng} \mathrm{m}^{-3}\end{array}$ & Keene et al. (2007) \\
\hline Volatile inorganic $\mathrm{Br} \& \mathrm{I}$ & \& U. Virginia) & & $\begin{array}{l}4.9 \text { and } 2.7 \mathrm{ng} \mathrm{m}^{-3} \\
(3 \mathrm{~h})\end{array}$ & \\
\hline Aerosol, size-resolved & Berner 5-stage impactor & & (24 to $48 \mathrm{~h})$ & \\
\hline $\begin{array}{l}\mathrm{Br}^{-}, \mathrm{Cl}^{-}, \mathrm{NO}_{3}^{-}, \mathrm{SO}_{4}^{2-}, \\
\text { dicarboxylic acids }\end{array}$ & Spectra Phoresis 1000 & Capillary Elecrophoresis & $\begin{array}{l}1,1,4,4 \\
0.2 \mathrm{ng} \mathrm{m}^{-3}\end{array}$ & Müller et al. (2009a) \\
\hline $\begin{array}{l}\mathrm{Mg}^{2+}, \mathrm{Ca}^{2+}, \mathrm{NH}_{4}^{+}, \\
\mathrm{Na}^{+}, \mathrm{K}^{+}\end{array}$ & $\begin{array}{l}\text { Metrohm } 690 \\
\text { (IfT, Leipzig) }\end{array}$ & Ion Chromatography & $\begin{array}{l}1,1,1 \\
1,1 \mathrm{ng} \mathrm{m}^{-3}\end{array}$ & \\
\hline $\mathrm{OC}, \mathrm{EC}$ & C-mat 5500 & NDIR & $0.02,0.01 \mu \mathrm{g} \mathrm{m}^{-3}$ & Herrmann et al. (2006) \\
\hline
\end{tabular}


Hourly VOC measurements were made using a dual channel gas chromatograph. The instrument has two parallel columns which simultaneously resolve $\mathrm{C}_{2}-\mathrm{C}_{8}$ NMHCs, and dimethylsulfide (DMS) using an $\mathrm{Al}_{2} \mathrm{O}_{3}$ PLOT column and oxidised volatile organic compounds (OVOCs), including acetaldehyde, methanol, and acetone using a more polar LOWOX column. VOCs were preconcentrated onto a multi-adsorbent bed at $\sim 18^{\circ} \mathrm{C}$ achieved through use of Peltier cooling and then desorbed into a helium flow by rapid heating $\left(16^{\circ} \mathrm{C} / \mathrm{s}\right)$ to $400^{\circ} \mathrm{C}$. NMHCs were calibrated using a standard cylinder (Apel-Reimer Environmental Inc., Denver, US) twice weekly whilst for DMS and OVOCs, a permeation system was used in conjunction with relative detector response. Weightings of the permeation tubes were typically carried out every two months. Measurements of $\mathrm{CO}$ were made using an Aerolaser 5001 fast response VUV analyser. The instrument was calibrated every $3 \mathrm{~h}$ using a $200 \mathrm{ppbv} \mathrm{CO}$ standard cylinder (BOC Gases, UK) which in turn was verified by the manufacturer and against other standard cylinders at the observatory. The time resolution for both $\mathrm{CO}$ and $\mathrm{O}_{3}$ measurements was $1 \mathrm{~min}$. CO, DMS, OVOCs and VOCs were measured from the top of the small tower, $10 \mathrm{~m}$ above ground level (20 m a.s.l.). A full description of the long term measurements of $\mathrm{CO}$ and VOCs can be found in Read et al. (2009).

Volatile halogenated trace gases were measured using the MADS (Modified Adsorption Desorption System) GCMS (Agilent) instrument in selective ion mode (SIM). The MADS takes 3-litre samples, through a counter-purged Nafion drier at a flow rate of $100 \mathrm{~mL} / \mathrm{min}$ and a frequency of $60 \mathrm{~min}$ per measurement. The trapping and injection unit consists of a microtrap for preconcentration which is cooled using two three-stage thermoelectric (Peltier) coolers to a temperature of $-40^{\circ} \mathrm{C}$ and then is independently heated resistively to $210^{\circ} \mathrm{C}$ in about four seconds. Separations are performed on a PoraBOND-Q capillary column, which is ramped from 40 to $220^{\circ} \mathrm{C}$ during the main analysis to allow less-volatile analytes to elute sharply. Each ambient air measurement was bracketed by the measurement of fixed loop injection of halocarbons from an oven containing permeation tubes of halocarbon standards. For compounds not contained in permeation tubes, a secondary method of calibration utilised calibration standards, which are generated at the University of Bristol from high concentration cylinders volumetrically diluted using a specially developed system. The field standards (contained in pressurized 35L Essex Cryogenic stainless steel canisters) are inter-compared, before and after use, by reference to gold standards maintained at the University of Bristol and Scripps Institution of Oceanography (SIO). The concentrations determined in the standards cylinders are reported in a provisional scale. Blanks and instrument linearity's are measured routinely. Halocarbons are also measured from the top of a small tower, $10 \mathrm{~m}$ above ground level (20 $\mathrm{m}$ a.s.1.).
Temperature, relative humidity, and wind measurements are collected from 3 heights $(4,10,30 \mathrm{~m}$ above ground level) every second and the data is averaged over a minute. Atmospheric pressure and broadband UV radiation is recorded at $4 \mathrm{~m}$. $j \mathrm{O}\left({ }^{1} \mathrm{D}\right)$ was measured at $4 \mathrm{~m}$ with a $2 \pi$ filter radiometer (Meteorology Consult Gmbh, calibrated before and after the field measurements) with $<5 \%$ precision and $\sim 20 \%$ accuracy for solar zenith angles (SZA) below $60^{\circ}$, and corrections were applied for the vertical overhead $\mathrm{O}_{3}$ column and changes in sensitivity due to changing SZA.

Continuous long-term analyses of aerosol ion composition, organic carbon, elemental carbon (OC/EC) and total mass have been made since January 2007 from 72-h samples taken at $32 \mathrm{~m}$ above the ground ( $42 \mathrm{~m}$ a.s.1.). Quality control is made twice a year for ion analysis by the WMO and the OC/EC method was part of an international round robin test reported in Schmid et al. (2001). An increased measurement frequency was used for the RHaMBLe intensive period (see below). A more detailed description is given in Müller et al. (2009a).

Within the RHaMBLE framework, a long-path broadband differential optical absorption spectrometer (DOAS) (Plane and Saiz-Lopez, 2006) instrument was deployed as a longterm instrument from the same container as the halocarbon GC/MS instrument. The instrument comprises a $450 \mathrm{~W}$ xenon lamp at the focal point of a $32 \mathrm{~cm}$ diameter Newtonian telescope, producing a collimated beam which is directed towards a retroreflector array. The returning light is captured by the same telescope and dispersed through a $0.5 \mathrm{~m}$ Czerny-Turner spectrometer with a 1200 grooves $\mathrm{mm}^{-1}$ grating, producing a spectral resolution of $0.25 \mathrm{~nm}$ over a range of $\sim 40 \mathrm{~nm}$ on a 1024-element CCD camera. Recorded spectra are converted into optical densities using a Fast Fourier Transform (FFT) (e.g. Plane and Saiz-Lopez, 2006), and the contributions of the individual absorbing species are then determined by using singular value decomposition to fit simultaneously a library of reference absorption cross-sections (Saiz-Lopez et al., 2004b). With DL for BrO (0.8 pptv), IO (0.5 pptv), $\mathrm{I}_{2}(10 \mathrm{pptv})$ and OIO (4 pptv) for a light-path of around $12 \mathrm{~km}$ and an averaging time of $20 \mathrm{~min}$, the DOAS instrument provided a continuous and long-term dataset of halogen radical measurements. More details can be found in Mahajan et al. (2009).

The intensive study was carried out in May and June 2007. For this period, a fluorescence assay by gas expansion (FAGE) instrument housed in a foreshore container provided in situ $\mathrm{OH}$ and $\mathrm{HO}_{2}$ concentrations. The instrument, described in Whalley et al. (2009) (as is the filter radiometer for $\left.j \mathrm{O}\left({ }^{1} \mathrm{D}\right)\right)$, comprises a wavelength tuneable Nd:YAGpumped Ti:Sapphire laser, generating up to $1.6 \mathrm{~W}$ of broadband near-IR radiation, from which a wavelength close to $924 \mathrm{~nm}$ is selected and frequency tripled to produce the required UV radiation close to $308 \mathrm{~nm}$ for $\mathrm{OH}$ excitation. The on-resonance laser induced fluorescence at low pressure is detected after correction for scattered laser light and detector 
dark counts by off-resonance tuning. $\mathrm{HO}_{2}$ was also measured by this method following conversion to $\mathrm{OH}$ by addition of NO. A DL of 0.04 and $0.1 \mathrm{pptv}$ for $150 \mathrm{~s}$ integrations was achieved for $\mathrm{OH}$ and $\mathrm{HO}_{2}$, respectively.

Collaboratory participation for the RHaMBLe intensive period provided quantification of a complementary suite of atmospheric constituents: $\mathrm{Cl}^{*}$ (including $\mathrm{Cl}_{2}, \mathrm{HOCl}$ and probably contributions from $\mathrm{ClNO}_{3}, \mathrm{ClNO}_{2}, \mathrm{BrCl}, \mathrm{ClO}$ and $\mathrm{Cl}$ ) was sampled atop the tower over 2-h intervals at nominal flow rates of $15 \mathrm{Lmin}^{-1}$ with tandem mist chambers containing $20 \mathrm{ml}$ acidic (upstream) and alkaline (downstream) scrubbing solutions (Keene et al., 1993, 2007; Maben et al., 1995). Water-soluble volatile inorganic chlorine and oxidised nitrogen (dominated by and hereafter referred to as $\mathrm{HCl}$ and $\mathrm{HNO}_{3}$, respectively), $\mathrm{NH}_{3}, \mathrm{HCOOH}$ and $\mathrm{CH}_{3} \mathrm{COOH}$ were sampled in parallel with tandem mist-chambers, each of which contained $20 \mathrm{ml}$ deionised water (Keene et al., 2007). Super- and sub- $\mu \mathrm{m}$ aerosol particles were removed by inertial size-fractionation at the inlet and in-line filtration, respectively, upstream of both sets of tandem samplers. Mist solutions were analysed on site by ion chromatography and blank-corrected. Average DLs (estimated following Keene et al., 1989) for $\mathrm{Cl}^{*}, \mathrm{HCl}, \mathrm{HNO}_{3}, \mathrm{NH}_{3}, \mathrm{HCOOH}$, and $\mathrm{CH}_{3} \mathrm{COOH}$ were $14,26,12,3,29$, and 44 pptv, respectively.

Particulate $\mathrm{Br}, \mathrm{I}, \mathrm{Na}, \mathrm{Al}, \mathrm{Mn}$ and $\mathrm{V}$ were sampled in bulk atop the $30 \mathrm{~m}$ tower over nominal 3-h intervals at nominal flow rates of $80 \mathrm{~L} \mathrm{~min}^{-1}$ using precleaned $47-\mathrm{mm}$ diameter Whatman 41 filters (Pszenny et al., 2004; Keene et al., 2007). Total volatile inorganic $\mathrm{Br}$ and I were sampled downstream of the Whatman 41 filters on tandem Rayon filters (Schleicher and Schuell 5S) impregnated with $10 \% \mathrm{w} / \mathrm{v}$ $\mathrm{LiOH}+10 \% v / v$ glycerol (Rahn et al., 1976). Exposed filters were shipped frozen to Mount Washington Observatory for processing and were subsequently analyzed at the University of Rhode Island by neutron activation (Rahn et al., 1976; Keene et al., 2007). Average DLs (estimated following Currie, 1968) for particulate $\mathrm{Br}, \mathrm{I}, \mathrm{Na}, \mathrm{Al}, \mathrm{Mn}$ and $\mathrm{V}$ and for total volatile inorganic $\mathrm{Br}$ and I were 2.2, 0.94, 0.53, 0.022, 0.25, $0.55,4.9$, and $2.7 \mathrm{ng} \mathrm{m}^{-3}$.

During the RHaMBLe intensive period, in parallel to the DIGITEL high volume $(500 \mathrm{~L} / \mathrm{min})$ quartz-filter sampling of total particulates below $10 \mu \mathrm{m}$ diameter $\left(\mathrm{PM}_{10}\right)$ a five-stage Berner impactor was used to collect size-resolved particles in the fractions 0.05 to $0.14 \mu \mathrm{m}, 0.14$ to $0.42 \mu \mathrm{m}, 0.42$ to $1.2 \mu \mathrm{m}$, 1.2 to $3.5 \mu \mathrm{m}$ and 3.5 to $10 \mu \mathrm{m}$ aerodynamic diameter onto aluminium foils at $75 \mathrm{~L} / \mathrm{min}$. All samples were analysed for water soluble ions $\left(\mathrm{Na}^{+}, \mathrm{NH}_{4}^{+}, \mathrm{K}^{+}, \mathrm{Mg}^{2+}, \mathrm{Ca}^{2+}, \mathrm{Cl}^{-}, \mathrm{Br}^{-}\right.$, $\mathrm{NO}_{3}^{-}, \mathrm{SO}_{4}^{2-}$, methanesulphonic acid, oxalate, malonate and succinate) by ion chromatography with conductivity detection or capillary electrophoresis with indirect UV detection. Organic and elemental carbon analyses were performed by a C-mat 5500 in a two step method using NDIR detection of $\mathrm{CO}_{2}$ (it should be noted that any differences between the loadings observed between the impactor and filter samples could be largely attributed to field blank values of the filters and the impaction foils). Additionally, pieces of thin polycarbonate foils were inserted on each stage for the analysis of metals using a S2-PICOFOX TXRF spectrometer. More details can be found in Müller et al. (2009a).

Aerosol size distribution measurements by scanning mobility and aerodynamic particle sizing instrumentation from $12.3 \mathrm{~nm}$ to $10.4 \mu \mathrm{m}$ diameter were made continuously from a container close to the tower with an inlet height of about $4 \mathrm{~m}$ above ground. Additionally, spectral absorption coefficients in the range from 350 to $950 \mathrm{~nm}$ were measured by the SOAP (Spectral Optical Absorption Photometer), using filter-based absorption photometry.

Gaseous dihalogen species $\left(\mathrm{Cl}_{2}, \mathrm{Br}_{2}, \mathrm{I}_{2}\right.$ and $\mathrm{BrCl}$ were measured using atmospheric pressure chemical ionisation tandem mass spectrometry (APCI-MS-MS) (Finley and Saltzman, 2008). The inlet was located on the foreshore at about $3 \mathrm{~m}$ above ground (13 $\mathrm{m}$ a.s.1.). Air was drawn through a $3 \mathrm{~m}$ multi-stage laminar flow inlet and ionised using a ${ }^{63} \mathrm{Ni}$ $\beta$-emitting foil to form anions from the respective ambient dihalogens. The dihalogen anions were mass filtered, collisionally dissociated to halogen ions, mass filtered again, then detected. The instrument blank was assessed by sampling ambient air through carbonate-coated glass wool. The instrument was field-calibrated using permeation tube standards. Permeation tubes were calibrated both gravimetrically and by reacting their output with neutral KI solution to form $\mathrm{I}_{3}^{-}$which was detected spectrophotometrically. The detection limits for dihalogens averaged $<2$ pptv for 15 min means.

\subsection{Ship characterisation of MBL chemistry variation with latitude and variable source region}

A spatial characterisation of the marine contribution to atmospheric halogen chemistry was provided by measurements made on the RRS Discovery cruise D319. The cruise mobilised from Lisbon and transected through Biscay, south past the Canary Isles, steaming onwards to Cape Verde with the following North-Easterly trade winds before docking in Mindelo on São Vicente during the intensive deployment at CVAO. The cruise then tracked towards the west coast of Africa, into the biologically-rich waters of the Mauritanian upwelling. The cruise tracked through gradients of productivity informed by realtime provision of remote-sensing products (see below); slowly tracking northwards, maximising useful atmospheric sampling by tacking into the prevailing wind. The cruise track overlaid onto remotely-sensed chlorophyll concentration retrieved from the MODIS satellite averaged across the period that the ship was in the region is shown in Fig. 2. D319 mobilised on 19 May and docked in Falmouth on 11 June 2007.

The aims of D319 were to quantify marine halocarbon emission variability and latitudinal heterogeneity, characterise in situ open ocean atmospheric reactive iodine latitudinal variability and the oxidative chemistry perturbation due 
to oceanic emission of halogens from the Mauritanian upwelling region; does the upwelling region produce more or less halogen compounds than the "background" region?

\subsubsection{Technique descriptions}

Table 2 lists the measurements and instruments on the RRS Discovery for D319.

A range of halocarbons were measured in both the water column and atmosphere by Two Perkin Elmer Turbomass GC-MS systems with thermal desorption units (TD, Perkin Elmer, UK). One instrument was used for continuous automated online air measurements (every $70 \mathrm{~min}$ ) and one for purge-and-trap water measurements (every 2 to $2.5 \mathrm{~h}$, 16 to $24 \mathrm{~h}$ per day). Air was sampled from $8 \mathrm{~m}$ above the ocean surface through a $60 \mathrm{~m}$ Teflon PFA sampling manifold at a flow rate of $\sim 30 \mathrm{~L} / \mathrm{min}, 100 \mathrm{~mL} / \mathrm{min}$ of which was sub-sampled through a clean metal bellows pump (Senior Aerospace, USA) to supply the online trap. $40 \mathrm{~mL}$ seawater samples were syringed from the non-toxic seawater supply drawn from, on average, $6 \mathrm{~m}$ below mean water line and injected into the purge-and-trap vessel. The techniques are described more fully in Carpenter et al. (2009) and provided halocarbon DLs in the range 0.01 to 0.05 pptv.

Two Broadband Cavity Enhanced Absorption Spectroscopy (BBCEAS) systems were deployed above and astern of the port side container with the aim of measuring boundary layer mixing ratios of $\mathrm{I}_{2}$ and IO. Each instrument comprised an open-path optical cavity (length $=117 \mathrm{~cm}$ ) formed between $25 \mathrm{~mm}$ diameter high reflectivity mirrors. The instrument targeting $\mathrm{I}_{2}$ employed a green light emitting diode (LED) and operated over the wavelength range 525$555 \mathrm{~nm}$ : this was the first field deployment of the instrument previously used to measure $I_{2}$ emissions from seaweed in the laboratory during the Roscoff coastal campaign (Ball et al., 2009). The second instrument used a royal blue LED to target IO absorption features within a bandwidth of 438$453 \mathrm{~nm}$, and was an adaptation of the LED-BBCEAS instrument deployed to measure the sum of $\mathrm{NO}_{3}+\mathrm{N}_{2} \mathrm{O}_{5}$ mixing ratios in ambient air during the Roscoff coastal campaign (Langridge et al., 2008).

A compact version of the FAGE system, developed for airborne measurement and modified for ship deployment, was located in the port container with an aim to quantify IO concentrations, permitting direct assessment of RHS-induced changes in the oxidising environment through the upwelling region. In contrast to the $\mathrm{HO}_{\mathrm{x}}$ FAGE, the ship instrument exploited the IO excitation wavelength at $445 \mathrm{~nm}$, with offresonance fluorescence at $520 \mathrm{~nm}$ (see Whalley et al., 2007).

NO measurements were made by chemiluminescence using an Ecophysics CLD 780 TR nitric oxide analyser. A second identical $\mathrm{NO}$ analyser was operated with a photolytic Xe lamp based $\mathrm{NO}_{2}$ converter (Ecophysics PLC 762) connected. Measurements were run on continuous sampling except during calibrations and when running zeros. The NO analysers were calibrated using a cylinder of $450 \mathrm{ppbv}$ NO in nitrogen, diluted to $4 \mathrm{ppbv}$ in zero air. The photolytic converter efficiency is also determined as part of the calibration using gas phase titration of $\mathrm{NO}$ to $\mathrm{NO}_{2}$ with ozone. Zero air was run through the system on several occasions to allow more accurate determination of the instrument artefact. Data was taken with $10 \mathrm{~min}$ integration period. The $1 \sigma$ limit of detection for $10 \mathrm{~min}$ frequency data is approximately $2.8 \mathrm{pptv}$ for $\mathrm{NO}$ and $7 \mathrm{pptv}$ for $\mathrm{NO}_{2}$. Ozone concentrations were measured using a 2B Technologies dual Cell UV absorption ozone analyser. The data is internally averaged to one minute frequency and the detection limit is 1.5 ppbv.

A spectral radiometer (Edwards and Monks, 2003) was sited on the monkey deck above the bridge of RRS Discovery. The radiometer provided continuous measurements of the solar actinic flux as a function of wavelength through an upward pointing $2 \pi$ hemisphere (wavelength range 280 $700 \mathrm{~nm}$; spectral resolution $1 \mathrm{~nm}$ ). The flux data were averaged to $1 \mathrm{~min}$ integration times and then combined with molecular absorption cross sections and quantum yields to calculate photolysis frequencies for $j \mathrm{O}\left({ }^{1} \mathrm{D}\right), j \mathrm{NO}_{2}, j \mathrm{NO}_{3}$, $\mathrm{jI}_{2}, j \mathrm{OIO}, j \mathrm{IO}, j \mathrm{CH}_{3} \mathrm{I}, j \mathrm{HOI}, j \mathrm{CH}_{2} \mathrm{I}_{2}, j \mathrm{CH}_{2} \mathrm{ICl}, j \mathrm{CH}_{2} \mathrm{IBr}$ etc., or summed in wavelength to provide the total actinic flux over the radiometer's bandwidth. For example at solar noon on 3 June 2007, a cloudless day during the transect of the Mauritanian upwelling, the photolysis frequencies for $\mathrm{NO}_{2}, \mathrm{I}_{2}, \mathrm{CH}_{3} \mathrm{I}$ and $\mathrm{CH}_{2} \mathrm{I}_{2}$ were $8.5 \times 10^{-3} \mathrm{~s}^{-1}, 0.16 \mathrm{~s}^{-1}$, $3.0 \times 10^{-6} \mathrm{~s}^{-1}$ and $7.7 \times 10^{-3} \mathrm{~s}^{-1}$, respectively. The spectral radiometer operated from 19 May 2007 until 9 June 2007 with very occasional missing data.

Aerosol number and size distribution measurements from $3 \mathrm{~nm}$ to $30 \mu \mathrm{m}$ were made by a combination of scanning mobility particle sizer (SMPS) and optical instrumentation (Grimm 1.108) and were supplemented with a full online and offline chemical and physical aerosol characterisation measurements funded under the UK NERC Aerosol Characterisation and Modelling in the Marine Environment (ACMME) programme (see Allan et al., 2009). These measurements included online sub- $\mu \mathrm{m}$ non-refractory aerosol composition by Aerodyne High-Resolution Aerosol Mass Spectrometer (AMS). Sub- and supersaturated water uptake were measured by hygroscopicity tandem differential mobility analyser (HTDMA Cubison et al., 2005; Gysel et al., 2009) and cloud condensation nucleus $(\mathrm{CCN})$ counter (Droplet Measurement Technologies) and are reported in Good et al. (2009). Particulate Black Carbon equivalent was measured by Multi-Angle Absorption Photometer (MAAP, ThermoScientific). Aerosol iodine speciation and major ion (including $\mathrm{Cl}^{-}$and $\mathrm{Br}^{-}$) chemistry were determined in sub- and super-micron aerosol particles collected using a high volume sampler and Sierra-type cascade impactor. Additional seawater bubble-tank experiments were conducted to investigate the chemical and physical properties of aerosol generated from seawater sampled at regular intervals throughout the cruise and funded through the UK NERC Characteristics Of 
Table 2. Measurement and instrument listing for the RHaMBLe cruise D319 on the RRS Discovery in May-June 2007.

\begin{tabular}{|c|c|c|c|c|}
\hline Target species & Instrument & Technique & DL (integration time) & Reference \\
\hline IO & $\begin{array}{l}\text { FAGE LIF } \\
\text { (U. Leeds) }\end{array}$ & $\begin{array}{l}\text { Laser Induced } \\
\text { Fluorescence at } 445 \mathrm{~nm}\end{array}$ & $0.23 \mathrm{pptv}(30 \mathrm{~min})$ & Whalley et al. (2007) \\
\hline $\begin{array}{l}\mathrm{IO}, \mathrm{I}_{2} \\
\mathrm{NO}_{2}, \text { blue/green } \lambda \mathrm{s}\end{array}$ & $\begin{array}{l}\text { BBCEAS } \\
\text { (U. Leicester \& Cambridge) }\end{array}$ & $\begin{array}{l}\text { LED Cavity Enhanced } \\
\text { Absorption Spectroscopy }\end{array}$ & $\begin{array}{l}20,200 \text { pptv, } \\
0.9 / 3 \text { ppbv }(10 \mathrm{~min})\end{array}$ & Langridge et al. (2008) \\
\hline $\begin{array}{l}\text { Halocarbons, } \\
\text { (air) }\end{array}$ & $\begin{array}{l}\text { GC/MS } \\
\text { (U. York) }\end{array}$ & $\begin{array}{l}\text { Gas chromatography } \\
\text { Mass Spectrometry }\end{array}$ & 0.05 pptv $(70 \mathrm{~min})$ & Carpenter et al. (2009) \\
\hline $\begin{array}{l}\text { Halocarbons, } \\
\text { (water) }\end{array}$ & $\begin{array}{l}\text { GC/MS } \\
\text { (U. York) }\end{array}$ & $\begin{array}{l}\text { Gas chromatography } \\
\text { Mass Spectrometry }\end{array}$ & $0.05 \mathrm{pptv}(2 \mathrm{hr})$ & Carpenter et al. (2009) \\
\hline Aerosol & $\begin{array}{l}\text { SMPS, CPC, OPC } \\
\text { (U. Manchester) }\end{array}$ & $\begin{array}{l}\text { Electrical mobility } \\
\text { sizing \& optical counting }\end{array}$ & $\mathrm{x} \mathrm{nm} \mathrm{m}^{-1} \mathrm{~cm}^{-3}(6 \mathrm{~min})$ & Allan et al. (2009) \\
\hline Aerosol & $\begin{array}{l}\text { Andersen \& CCI } \\
\text { (U. Manchester \& UEA) }\end{array}$ & $\begin{array}{l}\text { Hi-Vol \& lo-vol } \\
\text { cascade impactors }\end{array}$ & 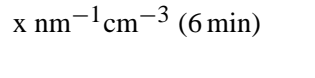 & Allan et al. (2009) \\
\hline Aerosol & $\begin{array}{l}\text { HTDMA, CCNc } \\
\text { (U. Manchester) }\end{array}$ & $\begin{array}{l}\text { Sub- \& supersaturated } \\
\text { water uptake }\end{array}$ & $\begin{array}{l}\mathrm{GF}_{\mathrm{D}, 90 \%} \pm 0.05(10 \mathrm{~min}) \\
\mathrm{S}_{\text {crit }} \pm 0.02 \%\end{array}$ & Allan et al. (2009) \\
\hline $\mathrm{O}_{3}$ & $\begin{array}{l}\text { 2B Technologies } \\
\text { (U. York) }\end{array}$ & uv absorption & $2 \mathrm{ppbv}(1 \mathrm{~min})$ & Lee et al. (2009) \\
\hline NO & $\begin{array}{l}\text { EcoPhysics CLD780 } \\
\text { (U. York) }\end{array}$ & Chemiluminescence & $1.5 p p t v(1 \mathrm{~min})$ & Lee et al. (2009) \\
\hline $\mathrm{NO}_{2}$ & $\begin{array}{l}\text { EcoPhysics CLD780 } \\
\text { (U. York) }\end{array}$ & $\begin{array}{l}\text { Photolytic conversion \& } \\
\text { Chemiluminescence }\end{array}$ & $5 p p t v(1 \mathrm{~min})$ & Lee et al. (2009) \\
\hline $\begin{array}{l}\text { Actinic flux \& } \\
\text { photolysis rates }\end{array}$ & $\begin{array}{l}\text { Spectral radiometers } \\
\text { (U. Leicester) }\end{array}$ & $\lambda$-resolved photon flux & $1 \mathrm{~min}$ & Edwards and Monks (2003) \\
\hline Photosynthetic pigments & $\begin{array}{l}\text { HPLC } \\
\text { (U. York) }\end{array}$ & $\begin{array}{l}\text { Liquid chromatography } \\
\text { of seawater samples }\end{array}$ & & \\
\hline $\begin{array}{l}\text { Wind speed, direction, } \\
\text { T, RH, PAR, TIR }\end{array}$ & $\begin{array}{l}\text { Foremast Met. Station } \\
\text { (UKORS core) }\end{array}$ & & & \\
\hline
\end{tabular}

Microlayer Produced AerosolS (COMPAS) project (Fuentes et al., 2010a,b).

Realtime prevailing synoptic meteorology and remotely sensed ocean parameters were used to direct the cruise in terms of geographical positioning and measurement interpretation to e.g. identify and exploit broad flow connection between CVAO and the ship to interpret measurements as process studies and identify in- and out-of-plume conditions to contrast chemistry influenced and uninfluenced by emissions from the upwelling region.

\subsection{Airborne characterisation of MBL chemistry}

The RHaMBLe project sought to identify the potential importance of a number of processes involving bromine and iodine reactions which may occur close to the sea surface with influence on ozone and secondary aerosol. Since many of the reactions occurring in these coupled cycles are extremely fast, there is potential that substantial near sea surface gradients may exist in radicals, ozone, organohalogens, hydrocarbons and potentially particles. This has been hypothesised in modelling studies of both marine and Polar regions, but not probed or tested in any detail via observation. The RHaMBLe project made measurements only at fixed heights above the sea surface - between 8 and $20 \mathrm{~m}$ for the ship and 5 to $40 \mathrm{~m}$ for the atmospheric observatory. The use of an aircraft added vertically resolved observations for a range of trace gases which may induce (e.g. iodocarbons) or be affected by (e.g. ozone) such ocean initiated chemistry. Using an aircraft allowed the study of chemical composition and physical structure above the fixed site of the observatory and alongside and above the RSS Discovery, from minimum operating altitude of around $30 \mathrm{~m}$, through the depth of the MBL and into the overlying free troposphere. The gradients observed in this study, for example in ozone, can then be used to place the fixed site observations in a wider context and be used as constraint or test for detailed 1-D or higher order modelling scheme which aims to recreate $\mathrm{HO}_{\mathrm{x}}$ and halogen chemistry in the boundary layer. Aircraft observations in the tropical Eastern North Atlantic were made in May and June 2007, at the same time that the D319 cruise was in the Cape Verde region.

The measurements were made on board the NERC Airborne Research Support Facility (ARSF) Dornier 228 aircraft, which was based at São Pedro airport, São Vicente, Cape Verde. This was close to Mindelo (the port call for the RRS Discovery), and the location of the CVAO.

\subsubsection{Technique descriptions}

A full list of aircraft instrumentation is given in Table 3.

The aircraft was essentially used as a highly instrumented sonde, with measurements including $\mathrm{O}_{3}$ (TEI 49i), $\mathrm{CO}$ (Aerolaser AL5003) and whole air samples for VOCs (followed by GC-FID detection). Measurements of the halocarbons $\mathrm{C}_{2} \mathrm{Cl}_{4}, \mathrm{CHCl}_{3}, \mathrm{CH}_{3} \mathrm{I}, \mathrm{CH}_{2} \mathrm{Br}_{2}, \mathrm{CHBr}_{2} \mathrm{Cl}$ and $\mathrm{CHBr}_{3}$ 
Table 3. Measurement and instrument listing for the ARSF Dornier aircraft during May-June 2007.

\begin{tabular}{|c|c|c|c|c|}
\hline Target species & Instrument & Technique & DL (integration time) & Reference \\
\hline $\mathrm{O}_{3}$ & $\begin{array}{l}\text { TEI 49i } \\
\text { (University of York) }\end{array}$ & UV absorption & 1 ppbv (10s) & N/A \\
\hline $\mathrm{CO}$ & $\begin{array}{l}\text { TEI } 43 \\
\text { (U. York) }\end{array}$ & UV fluorescence & $2 \mathrm{ppbv}(10 \mathrm{~s})$ & N/A \\
\hline DMS, oVOCs, VOCs & $\begin{array}{l}\text { Whole air sampling } \\
\text { (U. York) }\end{array}$ & $\begin{array}{l}\text { Gas chromatography/ } \\
\text { Flame Ionisation Detector }\end{array}$ & $1 \mathrm{pptv}(2.5 \mathrm{~min})$ & Hopkins et al. (2002) \\
\hline $\begin{array}{l}\text { Halocarbons, } \\
\mathrm{C}_{\mathrm{X}} \mathrm{H}_{\mathrm{y}} \mathrm{X}_{\mathrm{z}}\end{array}$ & $\begin{array}{l}\mu \text {-DIRAC } \\
\text { (U. Cambridge) }\end{array}$ & $\begin{array}{l}\text { Gas chromatography/ } \\
\text { Electron Capture Detector }\end{array}$ & $0.5 \mathrm{pptv}(2 \mathrm{~min})$ & O'Brien et al. (2009) \\
\hline
\end{tabular}

were made by GC-ECD and are reported in O'Brien et al. (2009). Measurements were also taken of detailed meteorological parameters and aircraft data $(10 \mathrm{~Hz}$ : Temperature, Pressure, Relative Humidity, Turbulence, GPS position) using an Aircraft Integrated Meteorological Measurement System (AIMMS) probe. The aircraft operated on $4 \mathrm{~d}$ over the CVAO, undertaking measurements at 6 altitudes (100, 200, $350,600,1400,2500 \mathrm{~m})$, the bottom four of which were inside the MBL. A flight sampling at all of these altitudes lasted approximately $2 \mathrm{~h}$, and 3 flights took place on each day (at approx 09:00, 13:00 and 16:00 UTC). This allowed diurnal cycles over the CVAO to be observed, which could be compared to data taken at ground level at CVAO. The aircraft measurements were tied to the ground data by sharing of calibration standards for $\mathrm{O}_{3}, \mathrm{CO}$, VOCs and halocarbons.

\subsection{Synoptic and mesoscale meteorology}

The CVAO is well situated to observe air masses well processed within the marine troposphere, with very rare pollution from local activities. It is located on a NE facing beach, free of any significant coastal features that could affect the chemistry in the boundary layer and faces the strong, consistent prevailing trade winds from the Atlantic Ocean. Back trajectories arriving at the Cape Verde observatory were calculated through the British Atmospheric Data Centre (BADC) from ECMWF (European Centre for MediumRange Weather Forecasting) meteorological analyses. Three dimensional trajectories were integrated backwards in time for $8 \mathrm{~d}$. The trajectories were calculated $6 \mathrm{~h}$ intervals for arrival at the site at 00:00, 06:00, 12:00 and 18:00 UTC, specified at a pressure level of $975 \mathrm{hPa}$. Trajectories were also calculated every $12 \mathrm{~h}$ arriving at the position of the ship during the D319 cruise. ECMWF analysis was also used to calculate boundary layer height for the region of the D319 cruise from 26 May to 2 June for the period that the Discovery was in the vicinity of the CVAO.

\subsection{Remote sensing support and underway meteorology}

For the purposes of cruise and flight planning, MODIS/Aqua ocean colour satellite Chl- $a$ images was provided daily along with Met Office synoptic charts, weather forecasts and predicted ocean mixed-layer depth by the NEODAAS Remote Sensing Group at Plymouth Marine Laboratory. In Fig. 2, the ship's track for D319 is overlaid on the composite Chl- $a$ image from May 2007. The halocarbon concentrations are related to the biological productivity variability in Sect. 3.3 and Fig. 11. Figure 3 shows the shiptrack of the RRS Discovery throughout cruise D319 with windbarbs showing windspeed and direction (barbs in 5 knot intervals) and coloured according to the total incident irradiation indicating daytime (warmer) and night-time (cooler). Figure 4 presents a time series of the temperature and RH throughout the cruise shaded according to the following discrete periods: a) transect from Lisbon to CV with port call in Mindelo, b) eastward transit towards African coast, c) detailed survey of biologically productive "Mauritanian upwelling" waters, d) northerly "zig-zag" in and out of productive waters, e) transit home to Falmouth from the Canaries.

\section{Results}

\subsection{Air mass classification for area}

The airmass trajectories throughout the D319 cruise were seldom completely clean marine, but could be classified into three broad regimes as shown in Fig. 5. Trajectories on the southbound (outward) leg, shown in lilac, are largely found to originate from the clean marine mid-Atlantic sector. The trajectories on the eastbound transit from Cape Verde to the upwelling region, shown in green, experience longrange transport of European air whilst trajectories after 28 May when the ship was close to the African coast, shown in red, all indicate more recent continental influence. 


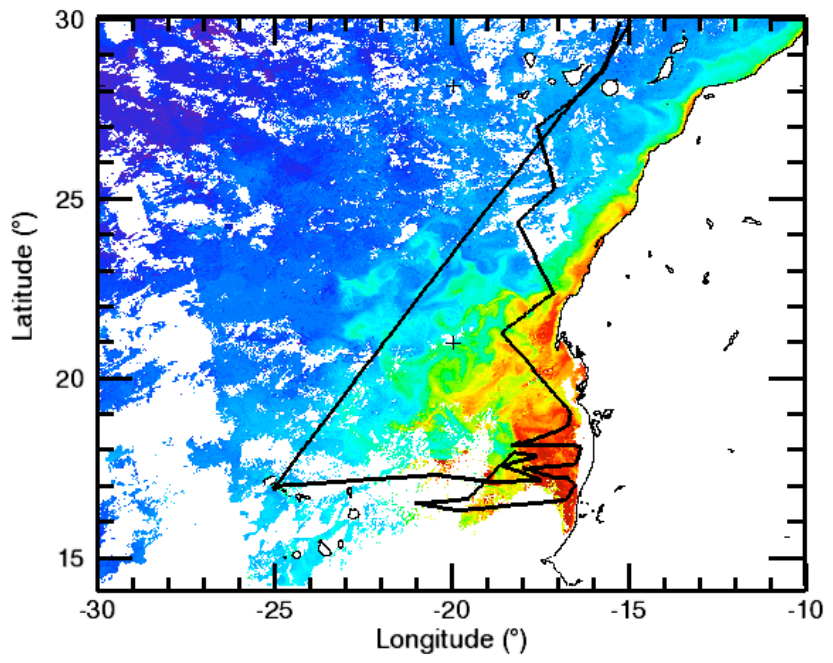

Fig. 2. Track of RHaMBLe Discovery Cruise D 319 in the working area south of $30^{\circ} \mathrm{N}$ with an overlay showing the MODIS retrieved chlorophyll a averaged for the month of May 2007.

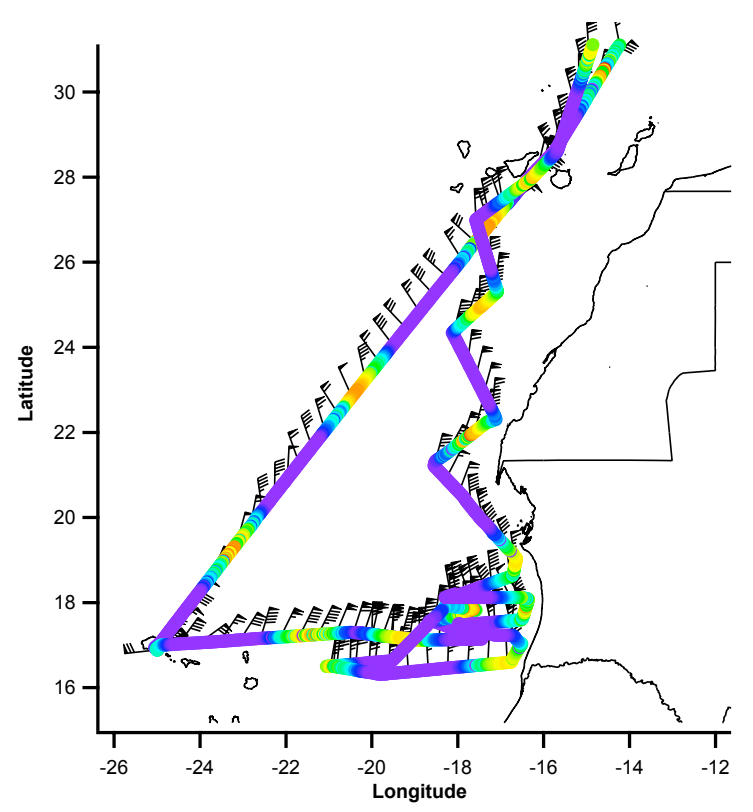

Fig. 3. D319 shiptrack showing windspeed and direction (windbarbs in 5 knot intervals) and coloured according to the total incident irradiation indicating daytime (warmer) and night-time (cooler).

No air originates over continental Africa during the cruise period, although when very close to the African coast, the air does pass over coastal West Africa and so will exhibit some continental influence. Figure 6 shows maps of the area of the D319 cruise $\left(14-22^{\circ} \mathrm{N} ; 26-16^{\circ} \mathrm{W}\right)$ coloured by ECMWF calculated boundary layer (BL) depth. The depth of the BL above the ship appears to be quite variable during the cruise period, with a general decrease in BL height closer to the

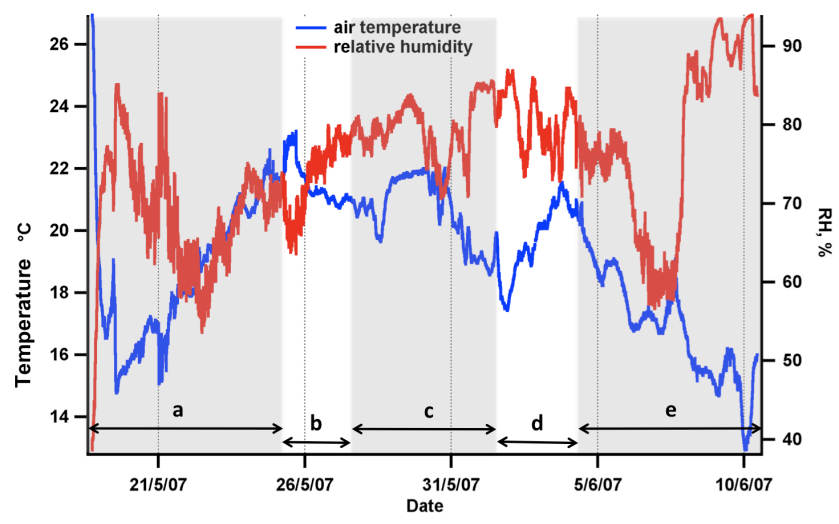

Fig. 4. Temperature and RH throughout D319. The time series are shaded according to several discrete period (a) transect from Lisbon to $\mathrm{CV}$ with port call in Mindelo, (b) eastward transit towards African coast, (c) detailed survey of biologically productive "Mauritanian upwelling" waters, (d) northerly "zig-zag" in and out of productive waters, (e) transit home to Falmouth from the Canaries.

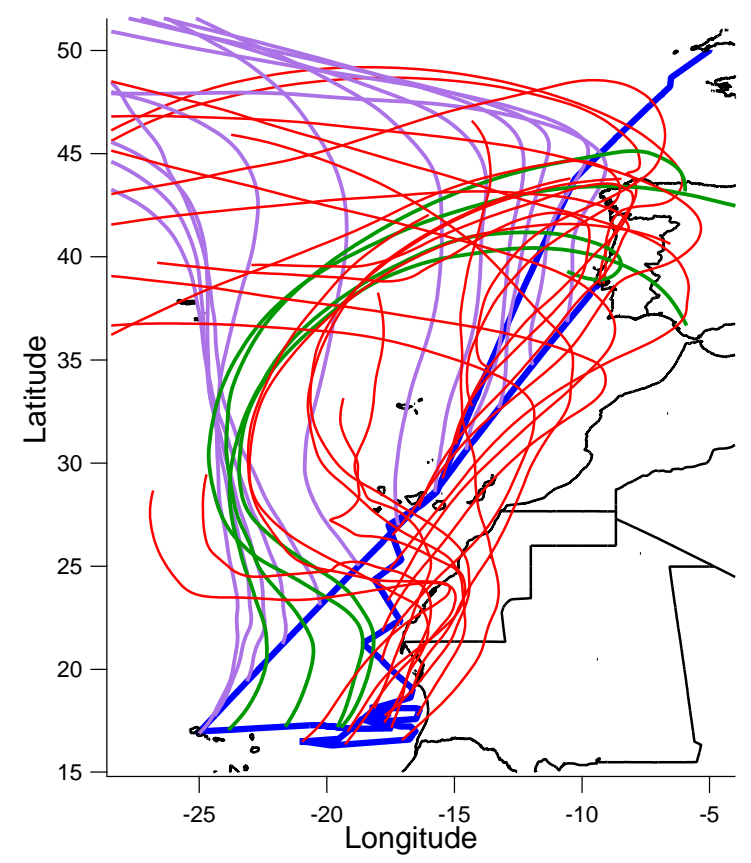

Fig. 5. 5-d back trajectories arriving at the location of RRS Discovery during cruise D319. The cruise track is shown in blue. Trajectories on the southbound (outward) leg, shown in lilac, are largely found to originate from the clean marine mid-Atlantic sector. The green trajectories on the eastbound transit from $\mathrm{CV}$ to the upwelling region experience long-range transport of European air whilst the red trajectories after 28 May all indicate more recent continental influence.

African coast. On 26 May, the BL height above the ship occurs at $\sim 700 \mathrm{~m}$, where as on 27 and 29 May, this value is lower $(\sim 400 \mathrm{~m})$. On 28 and 30 May the ship is very close to the African coast and the BL depth has decreased markedly 


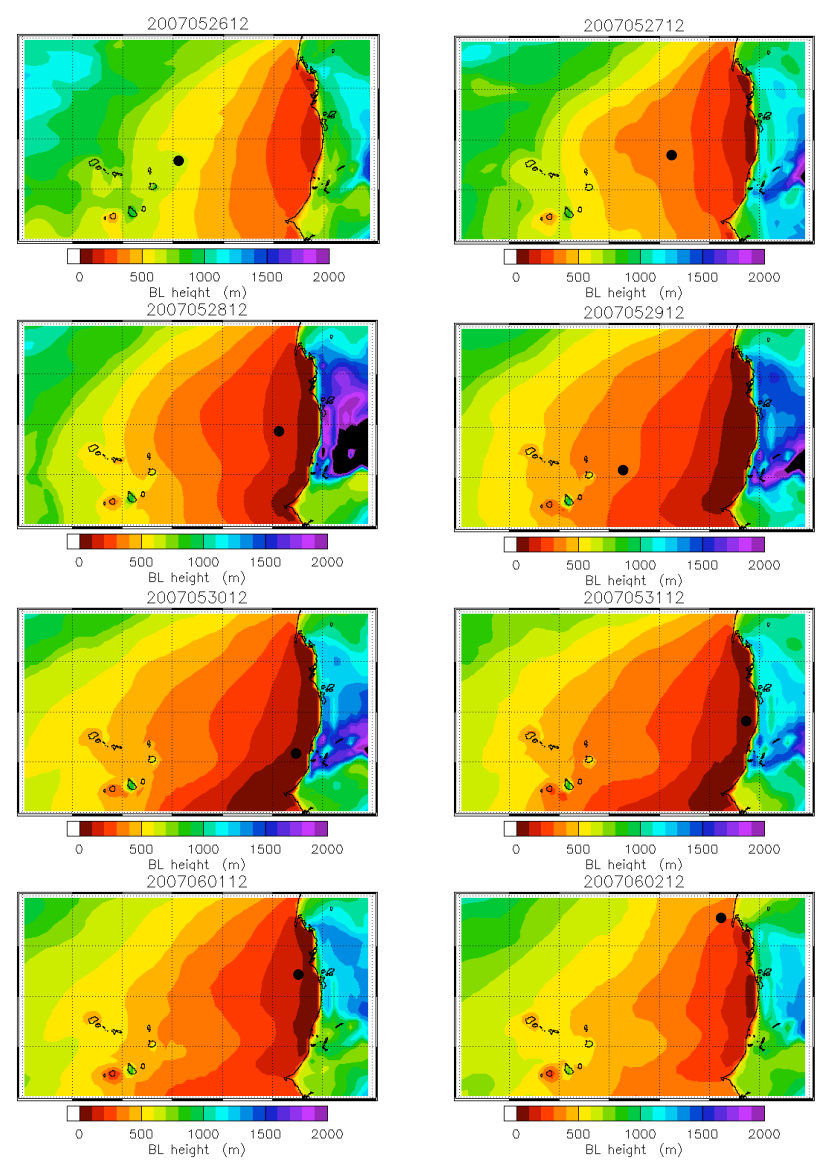

Fig. 6. ECMWF calculated boundary layer height at 12:00 UTC for each day of the D319 cruise on a grid spacing of $2^{\circ}$. The black circles represent the position of the ship at the time of the calculation.

to $\sim 200 \mathrm{~m}$. On 31 May to 2 June, the ship was on a Northerly track typically within $50 \mathrm{~km}$ of the African coast and was subject to an increasing BL depth as it proceeded north. On 31 May at about $18^{\circ} \mathrm{N}$, the depth of the BL was $\sim 100 \mathrm{~m}$, which increases to $\sim 200 \mathrm{~m}$ and $\sim 300 \mathrm{~m}$ on 1 and 2 June, respectively.

The RHaMBLe intensive study at the CVAO took place between 15 May and 10 June 2007, concurrent with the D319 cruise being in the region between Cape Verde and the African coast. Meteorological parameters for this time are shown in Fig. 7. As is usual for the region, surface wind direction was fairly constant during the intensive period, only varying between 25 and $60^{\circ}$. Surface wind speed is also generally high (6 to $\left.10 \mathrm{~ms}^{-1}\right)$, with the only exception being the period 5 to 9 June, when wind speed drops to below $4 \mathrm{~ms}^{-1}$. There was a slight diurnal variation in wind speed, with the highest values typically measured in late afternoon. The diurnal variation was more pronounced during the lower wind speed period. Temperature showed little diurnal variation; at the start of the intensive study, typically varying from $22^{\circ} \mathrm{C}$ at night to a maximum of $\sim 23^{\circ} \mathrm{C}$ in early afternoon. This value increased by about $1{ }^{\circ} \mathrm{C}$ by 10 June. Relative humidity varied between 75 and $85 \%$, with little diurnal variation with the exception of the period 6 to 9 June, which saw significant drops in relative humidity to $\sim 65 \%$ in the mornings. These days also saw higher temperatures (greater than $24^{\circ} \mathrm{C}$ ) and lower wind speeds compared to the rest of the intensive study. Probable explanation for the small diurnal temperature range when wind speeds are stronger is that diurnal variation in sea surface temperature is small and advection is from ocean, plus the boundary layer turbulence would be shear rather than buoyancy driven. This is particularly likely given the very strong wind shear across the top of the boundary layer in this region (see Sect. 3.4). Total radiation and $j \mathrm{O}\left({ }^{1} \mathrm{D}\right)$ also showed little day-to-day variability and indicate that the only days experiencing significant cloud cover were $1,2,8$ and 9 June. Typical peak noontime $j \mathrm{O}\left({ }^{1} \mathrm{D}\right)$ on cloud free days is around $4 \times 10^{-5} \mathrm{~s}^{-1}$.

Despite the relatively constant winds experienced at the CVAO, back trajectories show that air masses from a range of origins were sampled during the RHaMBLe intensive. $8 \mathrm{~d}$ back trajectories arriving at ground level at the CVAO at 12:00 UTC for each day of the RHaMBLe intensive are shown in Fig. 8. From 15 to 20 May the air originated in the remote North Atlantic, then passed close to or East of the Canary Islands, before arriving at the CVAO from a North Easterly direction.

The 21 May saw air originate much further away from Cape Verde in the Western North Atlantic, before passing over southern Iberia and arriving at the observatory from the NE. On 22 to 24 May, the air originated as far away as continental North America. On these days the origin of the air was at relatively low levels (within the boundary layer) over North America, before increasing in height over the Atlantic, then descending on the approach to Cape Verde. From 26 to 30 May, the CVAO experienced air that originated over the Mediterranean or Northern Sahara, (usually within the boundary layer), before passing near to the Canary Islands on its way to Cape Verde. For the remainder of the intensive period from late on the 30 May to 10 June, CVAO largely experienced air that was again mid-North Atlantic in origin, passing close to the Canary islands before approaching Cape Verde from a North Easterly direction (the 31 May may be considered as transitional between the two categories). Exceptions to this were 4 and 10 June where the air originated very close to the North American continent and 5 and 6 June where, although the air originated in the mid Atlantic passing at low level over southern Europe en route to Cape Verde.

\subsection{Measurements at CVAO}

The back trajectories can be framed in the context of some of the long term trace gas measurements and aerosol physical property measurements taken at the CVAO. Data series of $\mathrm{NO}, \mathrm{NO}_{2}, \mathrm{O}_{3}, \mathrm{CO}$, ethane, acetaldehyde, ethene and 

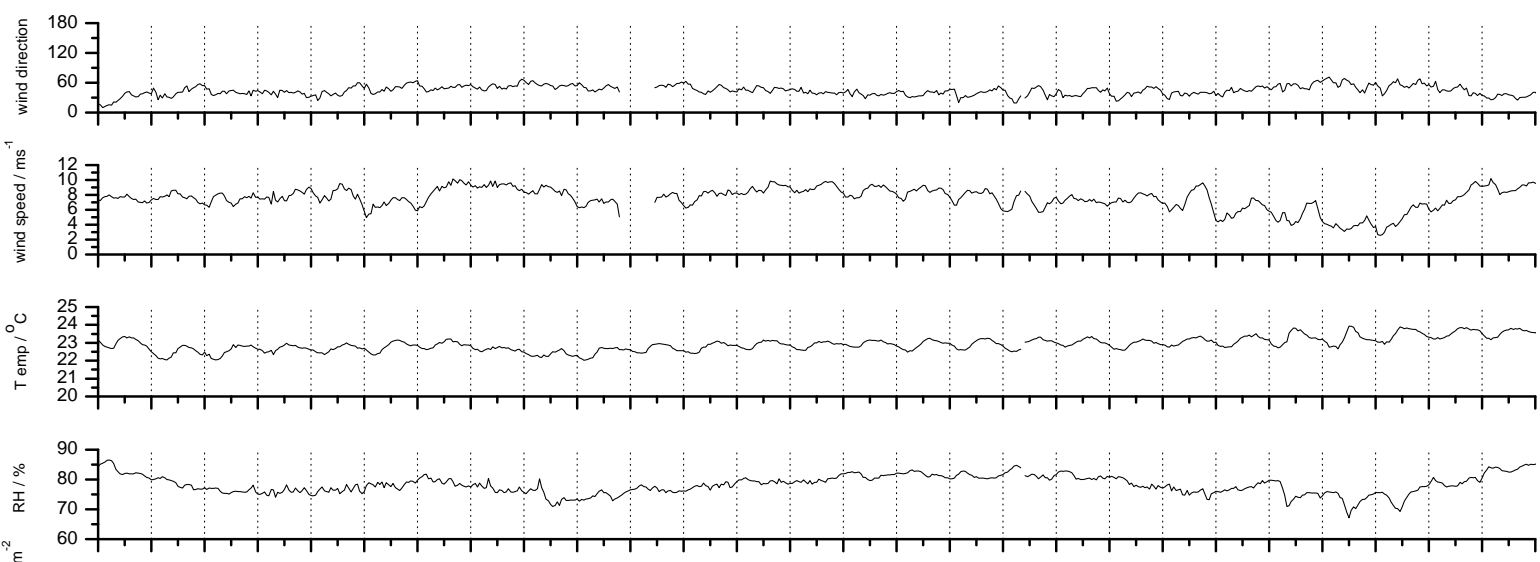

«
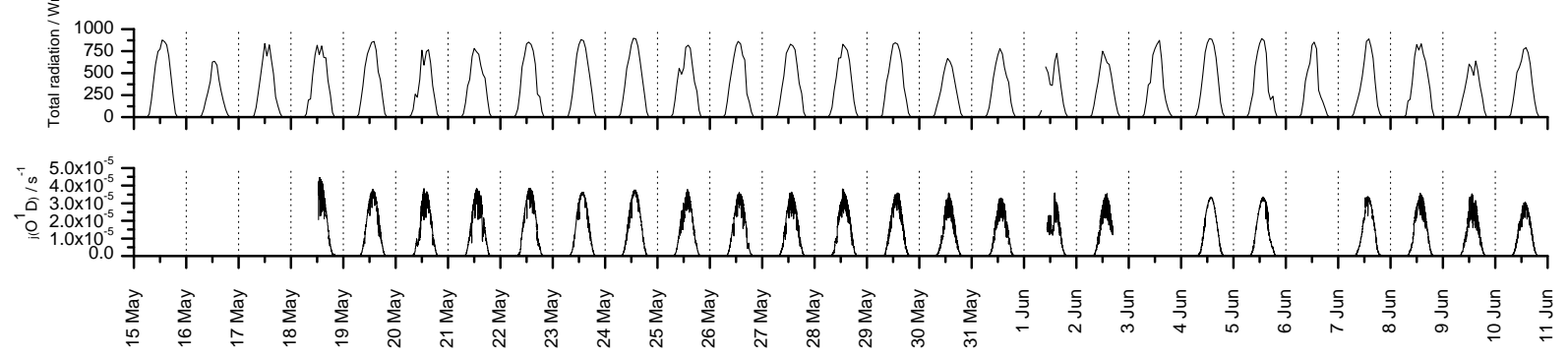

Fig. 7. Wind speed, direction, temperature, RH radiation and $j \mathrm{O}\left({ }^{1} \mathrm{D}\right)$ for CVAO for the duration of the RHaMBLe intensive (all measured at $5 \mathrm{~m}$ with hourly averaging).

acetylene from the RHaMBLe intensive period are shown in Fig. 9. The concentrations of the trace gases during the early part of the campaign (15 to 20 May) were extremely invariant and fairly low with average concentrations of $34.4 \pm 3.4 \mathrm{ppbv}$, $104.5 \pm 9.5 \mathrm{ppbv}, 834.5 \pm 96.5 \mathrm{pptv}$ and $112.8 \pm 12.6 \mathrm{pptv}$ observed for $\mathrm{O}_{3}, \mathrm{CO}$, ethane and acetylene, respectively. This behaviour is commonly observed at the CVAO and is consistent with air which has had minimal continental influence for at least $8 \mathrm{~d}$ and therefore has been well-processed in the marine boundary layer. Aerosol particle number and volume concentrations for this period ("Period 1") are around the mean value of the entire RHaMBLe intensive period (Fig. 10). Particle number size distribution (Fig. 11) shows typical maritime behavior with bimodal structure in the submicron and a slight third mode around $700 \mathrm{~nm}$. No influence except that of the ocean is visible.

For the most part the longer-lived gaseous species demonstrate similar tendencies throughout the measurement period consistent with their shared anthropogenic origins, except during the Western North Atlantic influenced period between the 21 and 22 May, when CO concentrations show an increase to $\sim 134 \mathrm{ppbv}$, whilst the longer-lived hydrocarbons (and $\mathrm{O}_{3}$ ) show respective decreases. At this time acetaldehyde also increases from $\sim 1000$ to $\sim 1300$ pptv and so this could potentially indicate secondary production of $\mathrm{CO}$ from oceanically produced VOC (Read et al., 2009). Diurnal trends in the acetaldehyde and alkene concentrations (ethene is plotted in Fig. 9 as an example) are observed for almost the entire measurement period but are particularly evident in air with an 8 day back trajectory over the Atlantic Ocean, in-line with suggestions of oceanic sources for these species (Ratte et al., 1998; Riemer et al., 2000; Zhou and Mopper, 1993). Similar diurnal behaviour has been observed in alkene measurements made at Mace Head on the west coast of Ireland (Lewis et al., 1999) and in the Indian Ocean (Bonsang et al., 2008) but very little literature is available of measurements of acetaldehyde in the marine boundary layer environment. On 21 through to noon on 22 May ("Period 2"), aerosol number and volume concentration show the highest values for the RHaMBLe intensive period. A high variability in the number concentration can be seen (Fig. 10). The higher volume concentration provides an indication of an increase in large particles in the atmosphere. Since wind speeds for this period were continuously high, sea spray may have been a dominant contributor to the volume. The bimodal structure of the submicron size distribution changed to a broader monomodal structure (Fig. 11), possibly a result of condensation of secondary material.

Evidence of long-range transport from America is observed between the 22 and 24 May with the air showing elevated average concentrations of $40.1 \pm 4.6 \mathrm{ppbv}$, $130 \pm 13.0 \mathrm{ppbv}, \quad 1230 \pm 103.6 \mathrm{pptv}, \quad 22.1 \pm 15.7 \mathrm{pptv}$ and $167.8 \pm 22$ pptv for $\mathrm{O}_{3}, \mathrm{CO}$, ethane, ethene and acetylene, respectively. Aerosol particle number concentration for this period ("Period 3") from noon on 22 through 24 May decreased and, since the volume concentration shows 

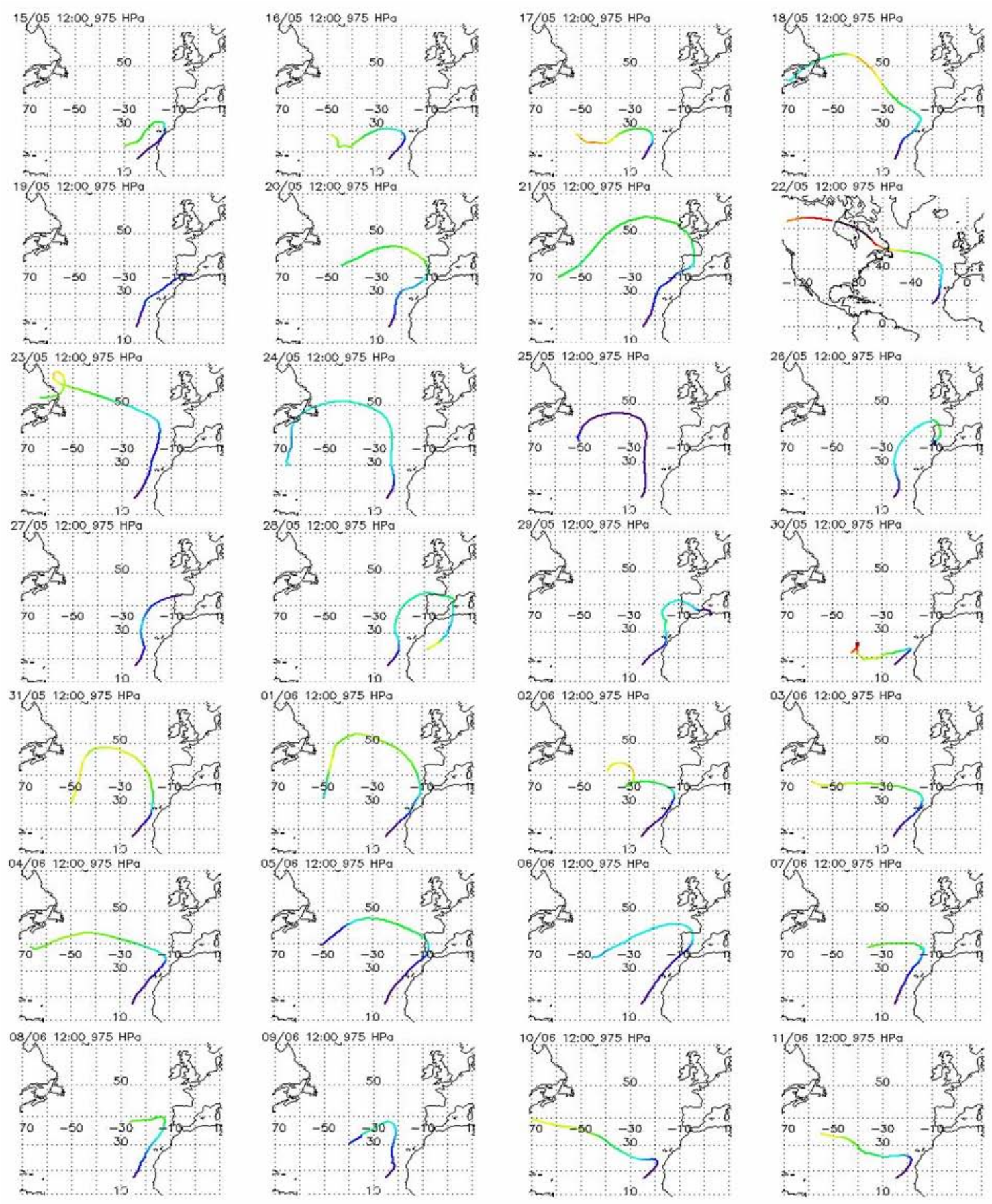

01/06 12:00 975 HP

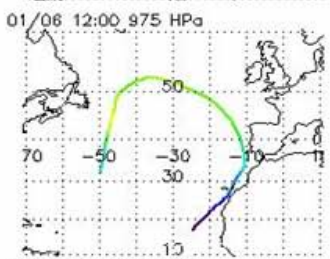

05/06 12:00 975 HP
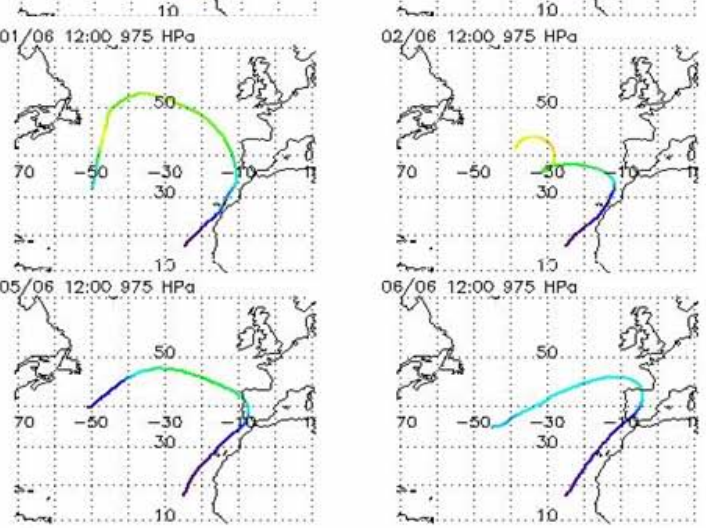

06/06 12:00 $975 \mathrm{HP}$
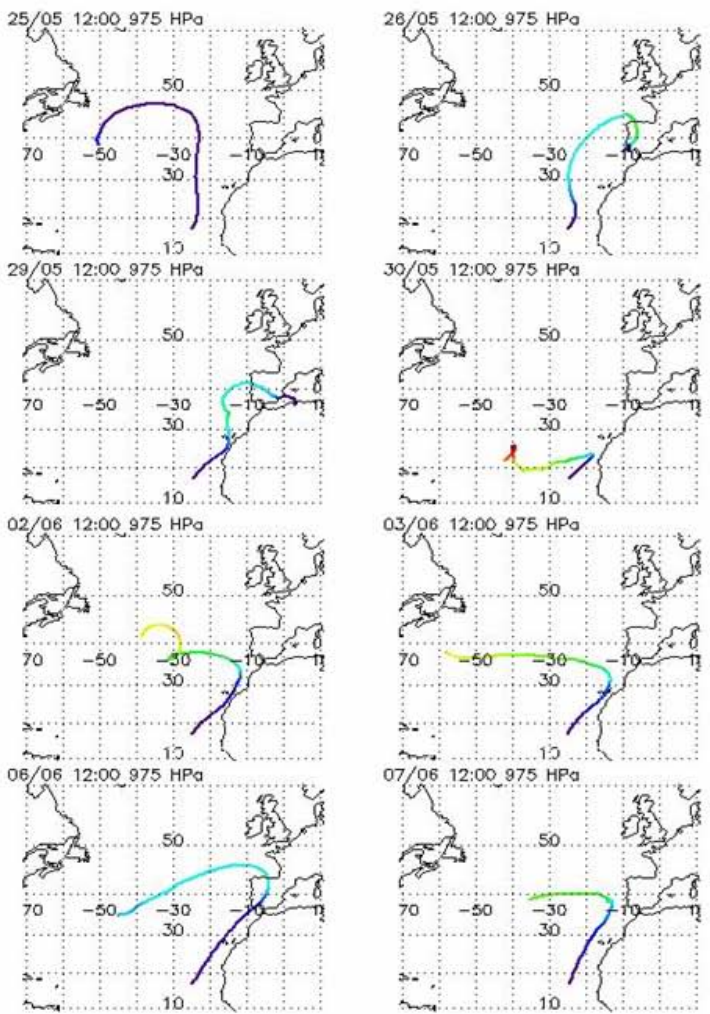

:-

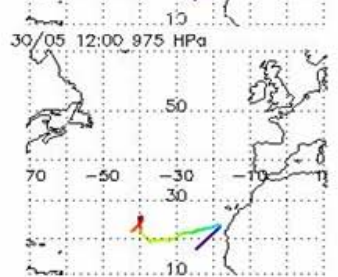

$$
\text { :- }
$$

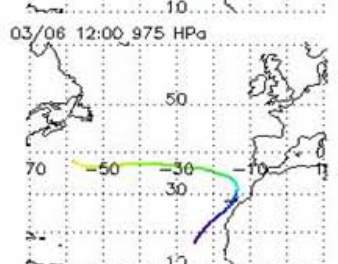

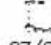

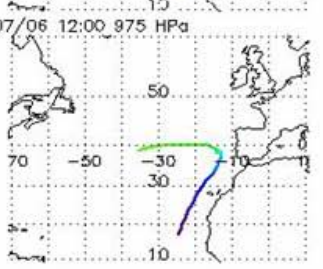

$09 / 06$ 12:00 975 HP
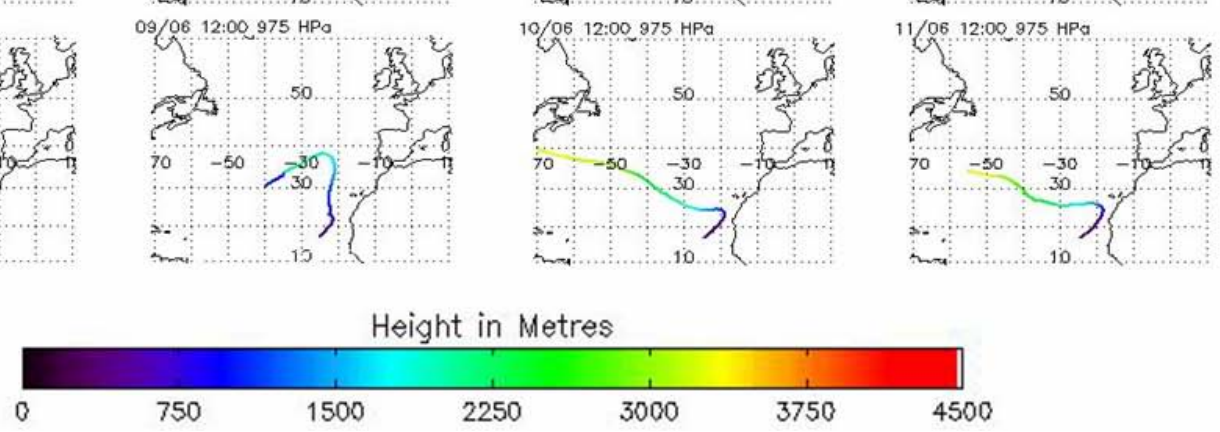

Fig. 8. 8 day back trajectories taken at midday for each day during the RHaMBLe intensive.

a similar value to Period 1, more large particles can be found compared to Period 1. This can also be seen in the particle number size distribution (Fig. 11), which also shows elevated concentrations in the first bins of the distribution
(12.3 to $30 \mathrm{~nm})$ which may be a result of "new particle formation" in this airmass.

Southern European emissions between 26 and 29 May do not appear to increase levels above those observed at the 


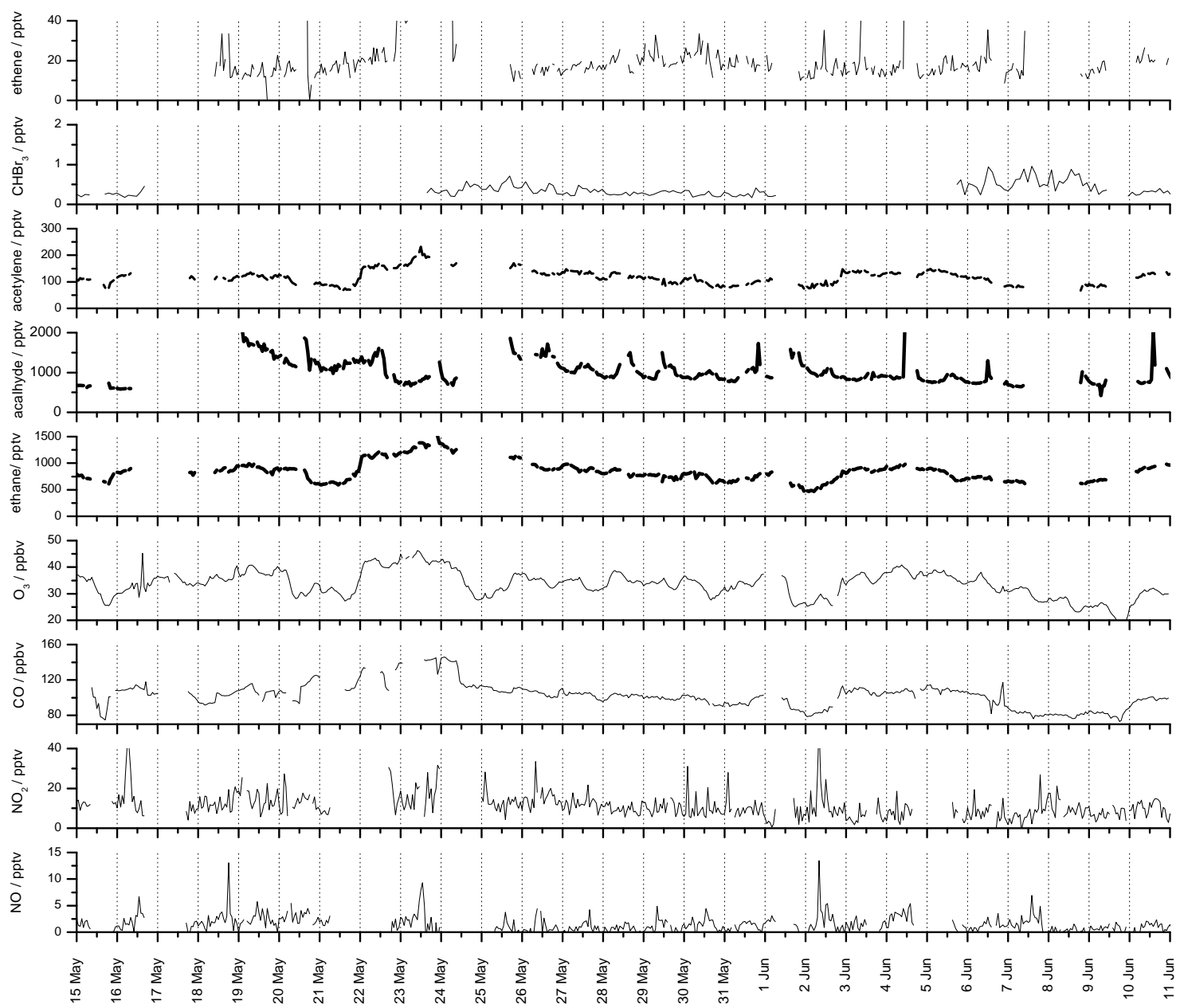

Fig. 9. Data series of selected trace species measured at the Cape Verde Atmospheric Observatory during the period of the RHaMBLe intensive. Data shown was sampled from a height of $5 \mathrm{~m}$ and is hourly averaged.

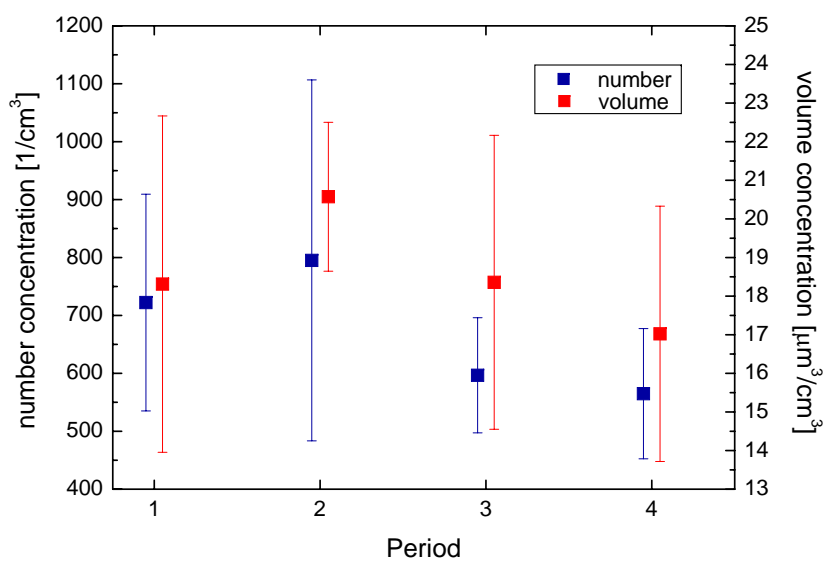

Fig. 10. Aerosol particle number and volume concentrations measured for each air mass period during the RHaMBLe intensive project.

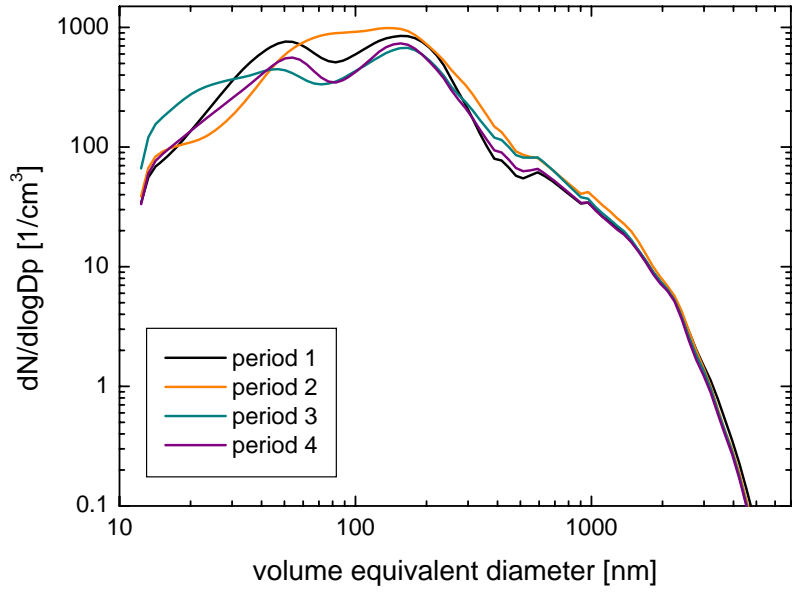

Fig. 11. Aerosol particle number size distributions averaged across each of the air mass periods during the RHaMBLe intensive project. 
beginning of the campaign despite the evidence of the 8-day back trajectory, and for the rest of the measurement period the trace gases gradually decrease to a low on the 9 June $\left(\mathrm{O}_{3}\right.$ $\sim 20$ ppbv and $\mathrm{CO} \sim 80 \mathrm{ppbv}$ ) during a period of consistently marine background influenced air masses. Slight elevations in the concentrations of $\mathrm{O}_{3}, \mathrm{CO}$ and the longer-lived hydrocarbons are observed with the influence of North American air on the 4, 5 and 10 June but otherwise the air during this period is invariant with respect to its origin, with low trace gas concentrations. This "Period 4" exhibits the lowest particle number and volume concentrations (Fig. 10), indicating that southern European emissions do not show any contribution to aerosol characteristics for this episode (as already observed in trace gas measurements). The size distribution is comparable to this in Period 1, with much lower concentrations in the submicron range, but showing the same shape (Fig. 11). Aerosol physical property measurements are further reported in Müller et al. (2009a).

$\mathrm{NO}$ and $\mathrm{NO}_{2}$ mixing ratios remained very low throughout the RHaMBLe intensive period. Peak daytime NO was usually $<5$ pptv, with $\mathrm{NO}_{2} \sim 15$ pptv. An exception to this was on 23 May during the period of longer range transport of the air mass, with peak $\mathrm{NO}$ at 10 pptv and $\mathrm{NO}_{2} \sim 25$ pptv. $\mathrm{NO}$ and $\mathrm{NO}_{2}$ are also both enhanced on 2 June (peak of 14 and 40 pptv for $\mathrm{NO}$ and $\mathrm{NO}_{2}$, respectively), although the air mass origin appears to be unchanged on this day compared to surrounding days. It is perhaps not surprising that $\mathrm{NO}_{\mathrm{x}}$ does not see the same variation in concentration with air mass origin during the RHaMBLe intensive period. Analysis of $\mathrm{NO}_{\mathrm{x}}$ from the whole of 2007 showed that $\mathrm{NO}_{\mathrm{x}}$ mixing ratios are virtually unchanged in all air masses except when the air originates over continental Africa before arriving at Cape Verde. In this air mass there is an enhancement of $\mathrm{NO}_{\mathrm{x}}$ by about 30\% (Lee et al., 2009). The 2007 dataset also showed that the amount of $\mathrm{O}_{3}$ destruction observed on any given day is linked to the $\mathrm{NO}_{\mathrm{x}}$ level. This also holds true during the RHaMBLe intensive, when the highest daily $\mathrm{O}_{3}$ destruction (5.5 and $7.1 \mathrm{ppbv}$ ) were observed on 8 and 9 June, days with the lowest NO levels $(\sim 1 \mathrm{pptv})$.

The $\mathrm{CHBr}_{3}$ mixing ratios measured throughout the RHaMBLe intensive by GC-MS are shown in the top panel of Fig. 9. The measurements are interrupted between 16 and 23 May and 1 and 6 June. The measured mixing ratios at the CVAO are in reasonable agreement with air measurements made aboard the RRS Discovery cruise D319 whilst in the vicinity of the CVAO (see Sect. 3.3), but are considerably lower than simultaneous measurements made at the site by GC-ECD, as reported in O'Brien et al. (2009), although the trends are in good agreement. This implies a calibration difference which is currently under investigation. The $\mathrm{CHBr}_{3}$ measurements show signs of a diurnal variation with a series of large excursions from baseline conditions between 25 and 27 May and more so between 7 and 11 June. The amplitude of the excursions ranged from $\sim 0.2$ to $0.7 \mathrm{pptv}$ with peak maxima occurring around midday. The magnitude of the el- evations and lack of correlation with anthropogenic species suggest that the source of $\mathrm{CHBr}_{3}$ during these periods may not be land based; this is further confirmed by analysis of back trajectories. This suggests that the probable source is ocean based as has been hypothesised for this nutrient rich region of high productivity. O'Brien et al. (2009) attributed a similar variation to local marine photochemical production. Mixing ratios of organoiodine compounds $\left(\mathrm{C}_{2} \mathrm{H}_{5} \mathrm{I}, 1-\right.$ and $2-\mathrm{C}_{3} \mathrm{H}_{7} \mathrm{I}, \mathrm{CH}_{2} \mathrm{ICl}$ and $\left.\mathrm{CH}_{2} \mathrm{I}_{2}\right)$ measured at the CVAO are low (0 to $0.5 \mathrm{pptv})$ but generally detectable. Averaging the data reveals diurnal patterns with generally higher $\mathrm{C}_{2} \mathrm{H}_{5} \mathrm{I}$ and $\mathrm{C}_{3} \mathrm{H}_{7} \mathrm{I}$ during the daytime, possible indicative of daytime photochemical sources, and daytime photochemical depletion of $\mathrm{CH}_{2} \mathrm{ICl}$ and $\mathrm{CH}_{2} \mathrm{I}_{2}$.

Further insight into the air mass classification during the RHaMBLe intensive period has been provided by interpretation of the eight-day back trajectories with respect to the mixing ratios of $\mathrm{Cl}_{2}$, soluble gases and aerosol composition, allowing categorisation according to the four following distinct regimes: Open Ocean-low sea salt (-lss), Open Ocean-high sea salt (-hss), Dusty, and Polluted Marine (Lawler et al., 2009). These categories are largely consistent with those presented above for $\mathrm{CO}, \mathrm{O}_{3}, \mathrm{NO}_{\mathrm{x}}$ and NMHCs.

Open Ocean-lss. These air masses typically originated in the subtropical or midlatitude free troposphere over the western North Atlantic Ocean or North America, circulated around a mid-Atlantic high pressure system, and subsided into the boundary layer 1.5 to $2.5 \mathrm{~d}$ north of Cape Verde (days 142 to 144, 22 to 24 May). These air masses reached Cape Verde without passing over Europe and exhibited generally low mixing ratios of soluble gases (Fig. 12), high $\mathrm{O}_{3}$ ( $\sim 43 \mathrm{ppbv}$ ), and low to moderate (74 to $181 \mathrm{nmol} \mathrm{Na} \mathrm{m}^{-3}$ ) sea salt. Nocturnal $\mathrm{Cl}_{2}$ was usually below $5 \mathrm{pptv}$.

Open Ocean-hss. Elevated levels of sea salt (up to $256 \mathrm{nmol} \mathrm{Na} \mathrm{m}{ }^{-3}$ ) were observed on days 152 to 154 ( 1 to 3 June). These air masses originated over the central or eastern North Atlantic, skirted the West African coast northeast of Cape Verde, and entered the MBL 2 to $2.5 \mathrm{~d}$ upwind of the site. $\mathrm{HNO}_{3}$ was $\sim 15 \mathrm{pptv}, \mathrm{NH}_{3}$ and carboxylic acids were generally less than DLs (Fig. 12), and $\mathrm{O}_{3}$ was $\sim 35$ ppbv. $\mathrm{Cl}_{2}$ had night time maxima of 5 to $15 \mathrm{pptv}$.

Dusty. This air mass type was sampled on days 147 to 150 (27 to 30 May) and was characterised by elevated levels of Al and Mn. Most air masses originated in the free troposphere over the Northwestern Sahara, then passed over Iberia before subsiding into the boundary layer $\sim 2 \mathrm{~d}$ north of Cape Verde. Dust levels were roughly two-fold higher at night than during the day but this trend was not obviously correlated with back trajectories. $\mathrm{HNO}_{3}$ was $\sim 12$ pptv, $\mathrm{NH}_{3}$ and carboxylic acids were usually less than DLs (Fig. 12), $\mathrm{O}_{3}$ was $\sim 35 \mathrm{ppbv}$, and $\mathrm{Na}$ increased from low to high levels ( 82 to $247 \mathrm{nmol} \mathrm{m}^{-3}$ ). $\mathrm{Cl}_{2}$ was near the detection limit, except for one day (150) when nocturnal mixing ratios reached 13 pptv. On 31 May the airmasses sampled may be regarded as transitional between dusty and open ocean. 


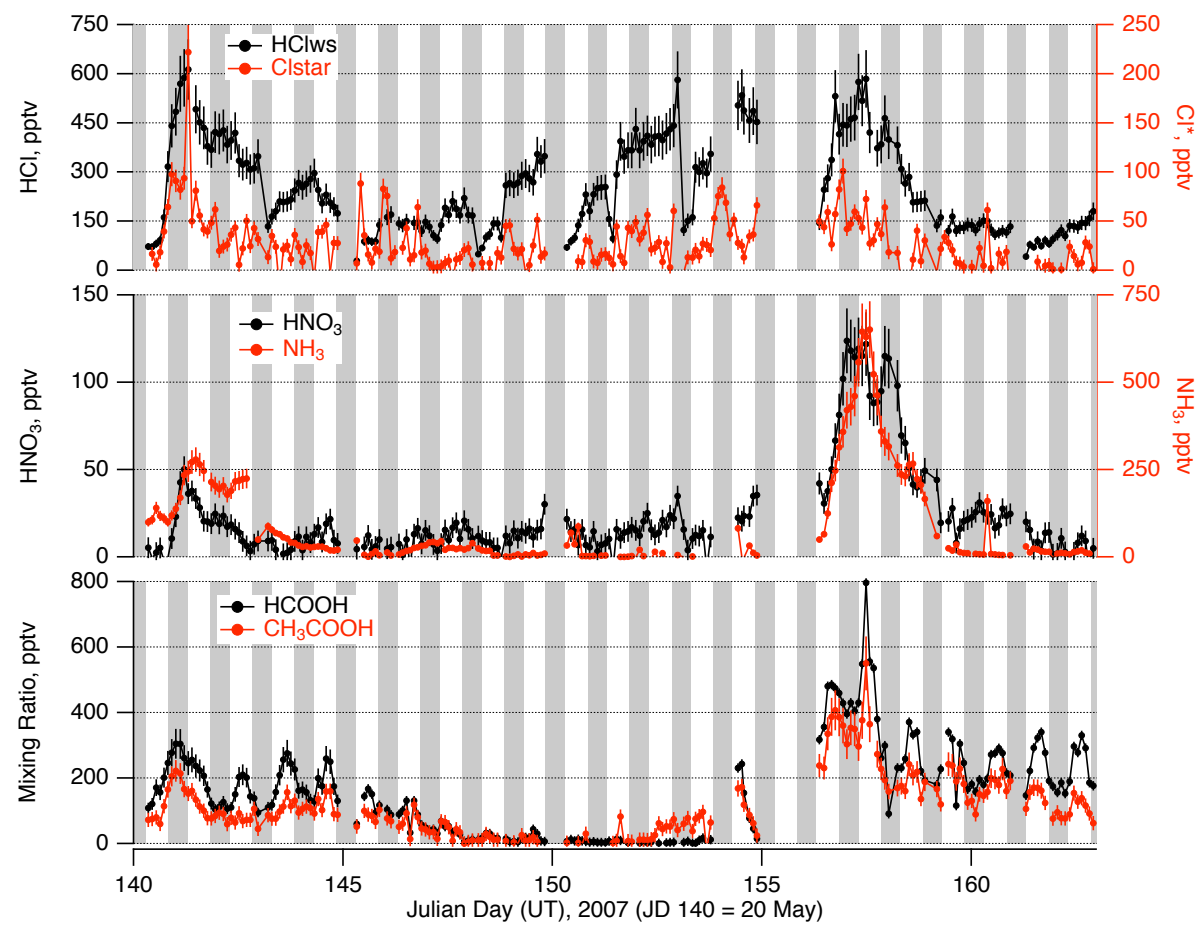

Fig. 12. Mixing ratios of water soluble gaseous components measured by tandem mist chamber (top panel, $\mathrm{Cl}$ species; middle panel, $\mathrm{HNO}_{3}$ and $\mathrm{NH}_{3}$; bottom panel, organic acids).

Polluted Marine. These conditions occurred when free tropospheric air from the central North Atlantic subsided into the boundary layer over Iberia 3 to $4.5 \mathrm{~d}$ upwind of Cape Verde (days 141, 21 May and 156 to 158,5 to 7 June). This air was characterised by elevated levels of $\mathrm{HNO}_{3}$ (up to $124 \mathrm{pptv}$ ), $\mathrm{NH}_{3}$ (up to $645 \mathrm{pptv}$ ), $\mathrm{HCOOH}$ (up to $796 \mathrm{pptv}$ ), and $\mathrm{CH}_{3} \mathrm{COOH}$ (up to $550 \mathrm{pptv}$ ); $\mathrm{O}_{3}$ of $\sim 35 \mathrm{ppbv}$ and moderate particulate $\mathrm{Na}$ ( 119 to $186 \mathrm{nmol} \mathrm{m}^{-3}$ ). These air masses exhibited the highest nocturnal $\mathrm{Cl}_{2}$ levels (up to $30 \mathrm{pptv}$ ) and, occasionally, daytime $\mathrm{Cl}_{2}$ levels above the detection limit (1 to 3 pptv).

Days 140 (20 May) and 159 (8 June) were transitional between Polluted, Open Ocean-lss, and Open Ocean-hss conditions. For these days, $\mathrm{Cl}_{2}$ night time maxima ranged from 10-15 pptv. Day 146 (26 May) was transitional between Open Ocean-lss and Dusty conditions. Day 145 (25 May) uniquely had an eight-day back trajectory entirely in the MBL, with low $\mathrm{Cl}_{2}$, low acids, and low sea salt.

$\mathrm{HCl}$ mixing ratios varied among regimes as a function of the relative mix of acids and sea salt. Maxima ( $\sim 600 \mathrm{pptv})$ were associated with polluted conditions on days 141 (21 May) and 157 (6 June) (Fig. 12).

Chemical composition of high volume (HV) aerosol filter and Berner impactor (BI) PM samples mainly comprised sea salt, mineral dust and associated water. African influence was generally small but air masses which from south-western Europe traversing the Canary Islands transported dust and other components to the CVAO. Total iron (dust vs. non- dust: 0.53 vs. $\left.0.06 \mu \mathrm{g} \mathrm{m}^{-3}\right)$, calcium ( 0.22 vs. $\left.0.03 \mu \mathrm{g} \mathrm{m}^{-3}\right)$ and potassium $\left(0.33\right.$ vs. $\left.0.02 \mu \mathrm{g} \mathrm{m}^{-3}\right)$ were good indicators for dust-influenced airmasses, being heavily elevated in the 1.2 to $3.5 \mu \mathrm{m}$ fraction compared with their concentration during non-dust periods. The mean mass concentration of $\mathrm{PM}_{10}$ was $17 \mu \mathrm{g} \mathrm{m}^{-3}$ from the impactor samples and $24.2 \mu \mathrm{g} \mathrm{m}^{-3}$ from HV filter samples. Non sea salt (nss) components were found in the sub- $\mu \mathrm{m}$ fractions along with nitrate in the coarse mode. Bromide was found to be heavily depleted in all samples (from 1 to $8 \mathrm{ng} \mathrm{m}^{-3}$ ) compared to fresh sea salt aerosol indicating intense atmospheric halogen activation. Chloride deficit was determined to be between 31 and $38 \%$ for the coarse mode particles ( 3.5 to $10 \mu \mathrm{m} ; 1.2$ to $3.5 \mu \mathrm{m}$ ) and of $67 \%(0.42$ to $1.2 \mu \mathrm{m})$ and $83 \%$ ( 0.14 to $0.42 \mu \mathrm{m})$ for the sub$\mu \mathrm{m}$ fractions.

The maximum organic $\left(1.71 \mu \mathrm{g} \mathrm{m}^{-3}\right)$ and elemental carbon $\left(1.25 \mathrm{\mu g} \mathrm{m}^{-3}\right)$ loadings were found on the dustinfluenced 14 May. The minimum total carbon loading $\left(0.25 \mu \mathrm{g} \mathrm{m}^{-3}\right)$ was detected during the period 25 to 27 May in clean marine air masses. The concentrations of carbonaceous material decrease with increasing particles size from $60 \%$ for the ultrafine particles to $2.5 \%$ in coarse mode PM. Oxalate (78 to $151 \mathrm{ng} \mathrm{m}^{-3}$ ) and methanesulfonic acid (MSA, 25 to $100 \mathrm{ng} \mathrm{m}^{-3}$ ) were the major organic compounds identified. A good correlation between nss-sulphate and MSA was found for the majority of days indicating active DMS chemistry and low anthropogenic influences. 
The results of the CVAO aerosol analyses are further reported in Müller et al. (2009a) and contrasted with the D319 aerosol analyses in Allan et al. (2009).

The LP-DOAS measurements indicate that $\mathrm{IO}$ and $\mathrm{BrO}$ were ubiquitously present whenever the solar zenith angle was less than $\sim 92^{\circ}$, i.e., throughout twilight and daylight conditions. Both the species were not measured above the detection limit during night time. The maximum concentrations observed over the campaign were $3.1 \pm 0.4 \mathrm{pptv}$ for IO and $5.6 \pm 1 \mathrm{pptv}$ for $\mathrm{BrO}$. However, on average the diurnal profile showed a "top-hat" distribution, with maximum values of $\sim 1.5$ pptv IO and $\sim 2.8$ pptv BrO seen between 09:00 and 17:00 GMT. The concentrations of IO and BrO did not show any correlation with the wind speed or wind direction. Neither species displayed any strong annual trend with the average values between 09:00 and 17:00 GMT staying fairly constant over the campaign. It should be noted that higher values were seen in spring (February-April), but the variability in the data does not allow a robust conclusion on the seasonal trend. The $\mathrm{I}_{2}$ and OIO concentrations were under the observed detection limit ( $10 \mathrm{pptv}$ and $4 \mathrm{pptv}$, respectively) for both species throughout the extent of the campaign. Interpretation of the measurements is further reported in Mahajan et al. (2009).

$\mathrm{HO}_{\mathrm{x}}$ radical concentrations recorded at the CVAO during the RHaMBLe intensive period were high, with maximum concentrations at midday of $\sim 0.4$ and $\sim 24 \mathrm{pptv}$ for $\mathrm{OH}$ and $\mathrm{HO}_{2}$, respectively. From the 21 to $24 \mathrm{May} \mathrm{HO}_{2}$ concentrations were most elevated as a consequence of the elevated $\mathrm{CO}$ and up to $2 \mathrm{pptv}$ of $\mathrm{HO}_{2}$ was recorded during the night time. From the 25 May onwards, $\mathrm{HO}_{2}$ concentrations were lower with a midday mixing ratio of $\sim 12$ pptv. The $\mathrm{HO}_{2}$ measurements are further reported in Whalley et al. (2009)

$\mathrm{Cl}_{2}$ levels during the study ranged from $<2$ to $30 \mathrm{pptv} . \mathrm{Cl}_{2}$ exhibited a marked diurnal cycle, with night time maxima and daytime minima and a mean levels of roughly 4 pptv. Periods of elevated $\mathrm{Cl}_{2}$ were strongly correlated with high levels of gaseous acids $\left(\mathrm{HNO}_{3}\right.$ and $\left.\mathrm{HCl}\right)$, and were related to air mass trajectories passing over the Iberian peninsula. Lawler et al. (2009) proposed that the elevated $\mathrm{Cl}_{2}$ was related to pollutant-enhanced acidification of marine aerosols and heterogeneous, autocatalytic $\mathrm{Cl}$ cycling. $\mathrm{BrCl}$ was not observed during this study, in contrast to model predictions based on known multiphase halogen chemistry.

\subsection{Horizontal extent of measurements}

The data from the CVAO described above can be further put in to context of the wider North Eastern Atlantic region by considering some of the trace gases and aerosol measurements made during the D319 cruise. Figure 13 shows the cruise track, coloured by total sub- $\mu \mathrm{m}$ organic aerosol loading $(\mathrm{OA})$, equivalent black carbon $(\mathrm{BC})$ loading, $\mathrm{NO}$ and $\mathrm{O}_{3}$. For all data sets, times that were believed to be influenced by ship stack emissions have been removed from the plot.
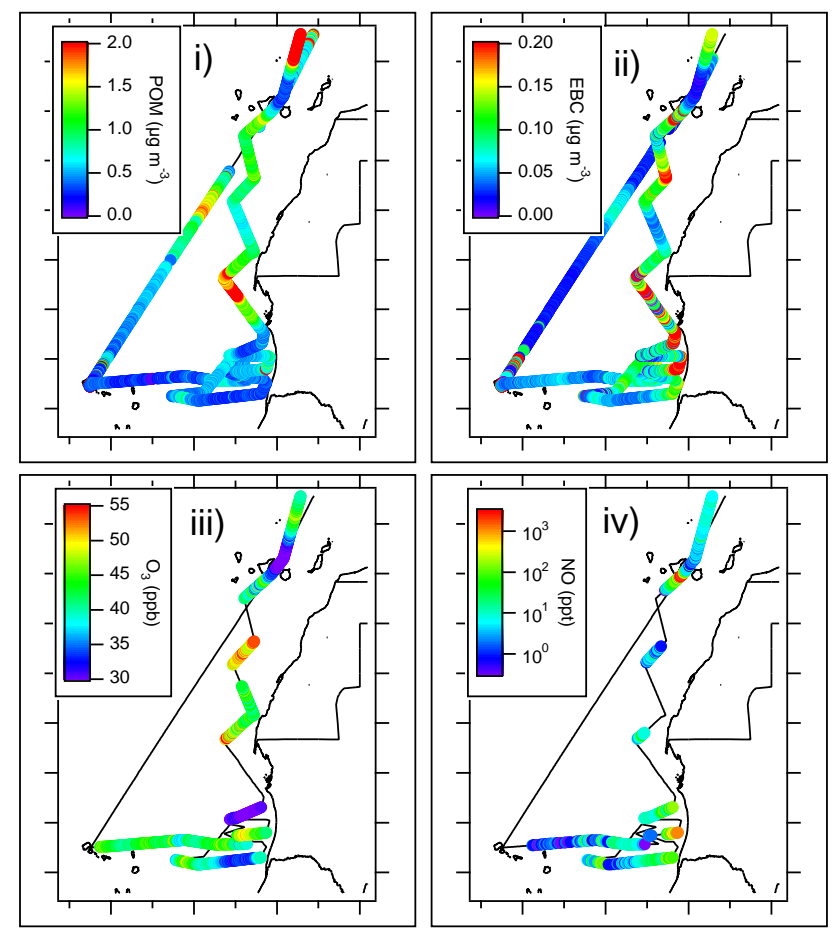

Fig. 13. D319 shiptracks coloured by (i) the total of all sub- $\mu \mathrm{m}$ organic aerosol components, (ii) equivalent black carbon concentration (as measured by the multi-angle absorption photometer), (iii) the $\mathrm{O}_{3}$ mixing ratio and (iv) $\mathrm{NO}$ mixing ratio.

Due to the position of the $\mathrm{NO}$ and $\mathrm{O}_{3}$ inlet on the port side of the ship, all data on the South heading from the Canary Islands has been removed, along with all data on legs when the ship was heading West. The particle measurements were taken from a shipping container on the bow of the ship (see Allan et al., 2009), which being further away from the ship stack, meant fewer data have been removed. BC and NO can be used as a tracer of anthropogenic influence of the air mass and there is a clear increase in both species from West to East along a line of longitude similar to that of Cape Verde. Peak daytime NO was observed to be $<5 \mathrm{pptv}$ in the region close to Cape Verde from $24^{\circ} \mathrm{W}$ to $21^{\circ} \mathrm{W}$. This is in good agreement with the NO levels observed at the CVAO (described above). BC levels in the same region are $<0.07 \mu \mathrm{gm}^{-3}$ which is consistent with the Northern Hemisphere remote marine boundary layer. NO mixing ratios started to increase from around $21^{\circ} \mathrm{W}$ reaching a maximum of $\sim 1 \mathrm{ppbv}$ at $16.5^{\circ} \mathrm{W}$, which is $\sim 50 \mathrm{~km}$ from the African coast. BC showed a similar pattern, with a maximum value of $\sim 0.07 \mathrm{~g} \mathrm{~m}^{-3}$ observed in a similar position to the maximum NO. $\mathrm{O}_{3}$ was observed to be 35 to $40 \mathrm{ppbv}$ close to the Cape Verde islands, again in good agreement with the measurements made at the CVAO. However there was no apparent increase in $\mathrm{O}_{3}$ as the ship headed East towards Africa, with lower levels (30 to $35 \mathrm{ppbv}$ ) measured on two of the 

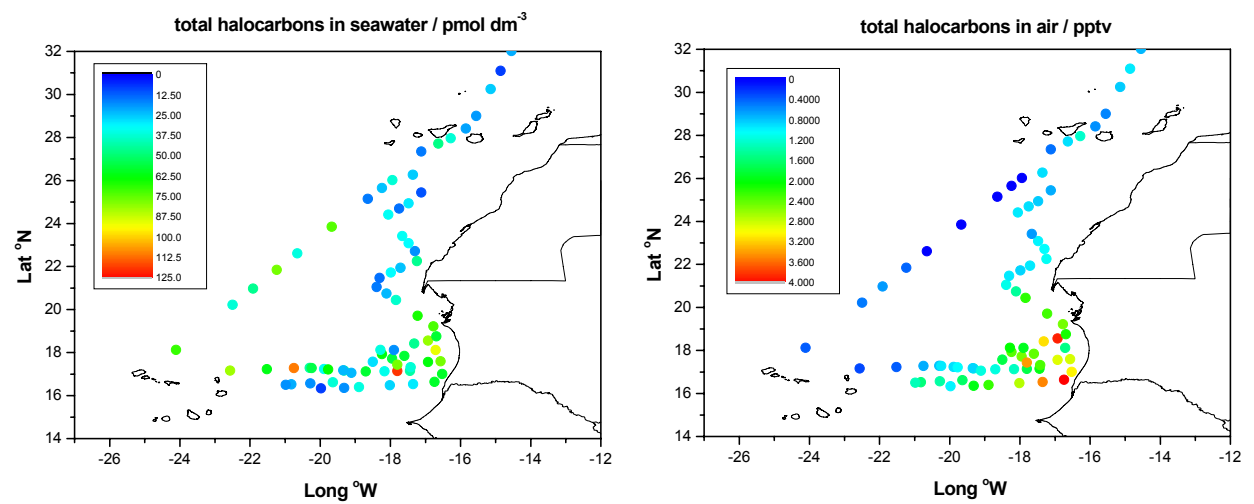

Fig. 14. D319 shiptrack coloured by total organic halogen mixing ratio in seawater (left) and air (right) as an indicator of marine biogenic activity.

East-West legs closer to the African coast. This suggests that the pollution observed here was very local in origin and the air had not been subject to much photochemical activity or that possible increased halogen activity in this region (which will be discussed later) has led to some ozone depletion. The African influence period on the boat was accompanied by an increase in the numbers of particles of all sizes, but particularly the Aitken mode (see Fig. 8 in Allan et al. (2009) for further details). Measurements of OA show very low levels $<0.5 \mu \mathrm{g} \mathrm{m}^{-3}$ for almost all the cruise at latitudes less than $19^{\circ} \mathrm{N}$, indicating that there are no periods during the cruise where elevated amounts of OA are unambiguously associated with air of clean marine origin.

Figure 14 shows the total halocarbon concentrations in both the air and surface seawater measured by GC-MS during the D319 cruise. The "Total halocarbons" corresponds to the sum of the observed $\mathrm{CH}_{3} \mathrm{I}, \mathrm{C}_{2} \mathrm{H}_{5} \mathrm{I}, \mathrm{CH}_{2} \mathrm{Br}_{2}$, $\mathrm{CH}_{2} \mathrm{ICl}, \mathrm{CH}_{2} \mathrm{IBr}, \mathrm{CHBr}_{3}$ and $\mathrm{CH}_{2} \mathrm{I}_{2}$ concentrations, where the cruise mean average mixing ratios in air for each species were found to range from 0.01 to $0.60 \mathrm{pptv}$. These volatile iodocarbons and bromocarbons are known to have a significant biogenic marine source, and hence the concentrations of these gases might be expected to increase in regions of high biological activity. It can be seen that the maximum halocarbon concentrations in both the water and air were observed east of Cape Verde within the Mauritanian upwelling region, supporting the hypothesis that these are nutrient rich waters which promote primary productivity, and may potentially be considered a regional halogen hot spot. The halocarbon seawater concentrations are comparable with those observed in this region in previous studies (Chuck et al., 2005; Quack et al., 2007), although the mixing ratios in air are typically lower than those previously reported, since these other studies were influenced by easterly trajectories from over the African continent and coast (Carpenter et al., 2009). The Carpenter et al. (2009) study compares the sea-air fluxes of biogenic bromocarbon compounds in this region calculated from measurement of their concentrations in seawa- ter and the atmosphere with those calculated from similar measurements during a North Atlantic cruise. Notably, the $\mathrm{CHBr}_{3}$ mixing ratios measured on board D319 in the vicinity of Cape Verde $\left(\sim 17^{\circ} \mathrm{N}, 20\right.$ to $\sim 24^{\circ} \mathrm{W}$, on the 26 of May) ranged from $\sim 0.3$ to $0.6 \mathrm{pptv}$, which is in a similar range to the values measured during the same period at the CVAO (see Fig. 9).

Demanding operating conditions during the D319 cruise prevented either BBCEAS instrument from achieving their usual sensitivities. Despite purging the custom-built mirror mounts with dry nitrogen, the mirrors' optical surfaces frequently became contaminated with sea salt and/or condensation, greatly reducing the effective path length of the measurements. Additionally, the shipping container housing the instruments' electronics experienced substantial temperature variations that compromised the stability of the LED light sources and the detectors. Absorption features attributable to several tens of ppbv $\mathrm{NO}_{2}$, most likely from the ship's own smoke stack, were evident in BBCEAS spectra obtained within the first few hours after cleaning and realigning the cavities, as were characteristic absorption bands around $443 \mathrm{~nm}$ (blue) and $545 \mathrm{~nm}$ (green) attributable to ambient water vapour (fitted mixing ratio $=2 \%$ ). Detection limits of 200 pptv for $\mathrm{I}_{2}$ and 20 pptv for IO for a 10 min acquisition time were estimated from the uncertainties in fitting the $\mathrm{NO}_{2}$ and $\mathrm{H}_{2} \mathrm{O}$ absorption features in the ambient BBCEAS spectra and the relative differential structure in the molecular absorption cross sections. Not unexpectedly, neither $\mathrm{I}_{2}$ nor IO was observed above these estimated detection limits during the D319 cruise.

Measurements during the D319 cruise together with those during previous investigations in the eastern North Atlantic MBL off West Africa (e.g. Williams et al., 2007; Keene et al., 2009; Lawler et al., 2009) indicate that concentrations of marine aerosols and the associated production of RHS precursors vary substantially (factor of $\sim 10$ ) over space and time. In addition, available evidence indicates that acids and acid precursors are typically present in this region at 
concentrations sufficient to titrate sea-salt alkalinity. Under these conditions, $\mathrm{Br}$ activation and the influences of $\mathrm{Br}$ radical chemistry on ozone, $\mathrm{HO}_{\mathrm{x}}$ and $\mathrm{NO}_{\mathrm{x}}$ vary, in part, as a function the production flux of $\mathrm{Br}^{-}$in association with marine aerosol (Keene et al., 2009), which implies that the vigour and impacts of halogen radical chemistry vary substantially across the region.

\subsection{Vertical extent of measurements}

Two different types of aircraft fights were undertaken around the CVAO and the ship in order to asses the representativeness of the ground measurements of the overlying boundary layer, to determine and diurnal variation on boundary layer depth and to assess the validity of the ECMWF calculations for interpretation of the ship based data. Figure 15a shows $\mathrm{O}_{3}$ and $\mathrm{CO}$ data from the 4 "observatory" flights along with data taken at the CVAO. It can be seen that data taken from the aircraft within the boundary layer shows excellent agreement with the observatory, with both the levels and diurnal cycle of both species being very similar. The top panel of Fig. 16 shows the vertical potential temperature profiles taken on the 3 flights on 27 May and demonstrates that there is a very strong temperature inversion; however there is no significant change the height of this inversion layer throughout the day. This is a function of the continuous strong winds and the invariant surface and sea surface temperature throughout the day. It is particularly important to consider the diurnal cycle of ozone in this analysis. The observed daytime ozone destruction cannot be explain using purely $\mathrm{HO}_{\mathrm{x}} / \mathrm{NO}_{\mathrm{x}}$ photochemistry at the CVAO, however with the addition of IO and $\mathrm{BrO}$ chemistry, the observed data has been reproduced by a photochemical model (Read et al., 2008). The fact that the ozone destruction is observed in all boundary layer aircraft measurements provides evidence that short lived halogen species may also be present throughout the entire boundary layer. All of these aircraft measurements and comparison to data from the CVAO, lead us to surmise that the ground measurements taken at the CVAO and thus in the surrounding ocean are representative of the overlying boundary layer. $\mathrm{O}_{3}$ data from the free troposphere shows much lower levels than measured the boundary layer. It is believed this results from air being sampled that originated further south than Cape Verde, towards the equator and within the Intertropical Convergence Zone (ITCZ). This is shown in Fig. 15b which shows $3 \mathrm{~d}$ back trajectories arriving above the CVAO on 27 May at heights approximately equivalent to the aircraft measurements. For the 2 heights within the boundary layer, air is from the North East, however above the inversion, air is seen to come from the South East. This means the air originated at $\sim 12^{\circ} \mathrm{N}$, which is close to the ITCZ for this time of year. These trajectories are typical for all days during the RHaMBLe intensive period. The diurnal behaviour of ozone in the free troposphere is very similar to that in the boundary layer, consistent with the same type of photochemistry

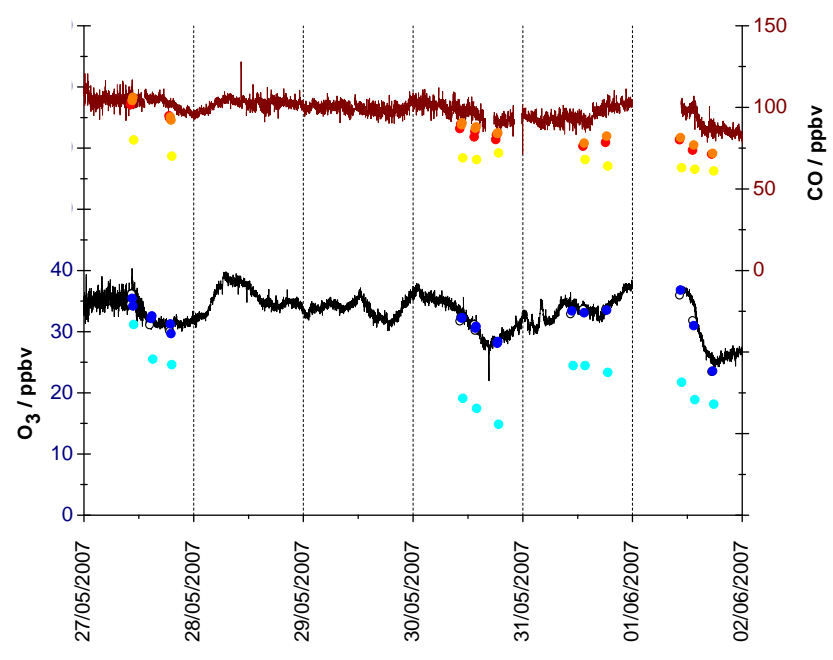

Fig. 15a. $\mathrm{O}_{3}$ and $\mathrm{CO}$ measured on 4 days at and above the Cape Verde atmospheric observatory. The solid lines show ground based data (black: $\mathrm{O}_{3}$ and red: $\mathrm{CO}$ ), the black $\left(\mathrm{O}_{3}\right)$ open circles and red (CO) points show lower boundary layer data (100-250 $\mathrm{m}$ a.s.1.), blue $\left(\mathrm{O}_{3}\right)$ and orange $(\mathrm{CO})$ points show upper boundary layer data (350-600 m a.s.1.) and the cyan $\left(\mathrm{O}_{3}\right)$ and yellow $(\mathrm{CO})$ points show free tropospheric data (1500-2500 m a.s.1.).

happening from a lower initial ozone concentration. $\mathrm{CO}$ also shows slightly lower levels in the free troposphere compared to the boundary layer, again supporting the hypothesis that air from close to the equator is being sampled.

Two flights took place that intercepted the D319 cruise on 26 and 29 May at $17^{\circ} 15^{\prime} 32^{\prime \prime} \mathrm{N}, 21^{\circ} 7^{\prime} 12^{\prime \prime} \mathrm{W}$ and $16^{\circ} 26^{\prime} 24^{\prime \prime} \mathrm{N}, 20^{\circ} 21^{\prime} 36^{\prime \prime} \mathrm{W}$, respectively (about $450 \mathrm{~km}$ from the CVAO). The vertical profiles over the ship gave a measurement of boundary layer height and could be compared to the height interpreted from the ECMWF calculated boundary layer heights described in Sect. 3.1. On the day of the first flight, Fig. 6 suggests the inversion layer at the position of the ship is at $\sim 700 \mathrm{~m}$ and this is confirmed by the potential temperature profile shown for this flight in the middle panel of Fig. 16. On 29 May, the calculated boundary layer height shown in Fig. 6 is much lower at around $\sim 400 \mathrm{~m}$, which is again confirmed by the potential temperature profile measured from the aircraft and shown in the bottom panel of Fig. 16. These measurements give confidence that the ECMWF analysis can be used to assess boundary layer height for the entire D319 cruise period.

\subsection{The chemical context for halogen recycling and its impacts}

The roles of odd-hydrogen chemistry in the marine environment are reasonably well-established. Under clean marine conditions in the absence of halogens, the $\mathrm{HO}_{\mathrm{x}}$ budget and oxidising capacity may be reasonably described by primary production from $\mathrm{O}_{3}$ photolysis with $\mathrm{OH}$ lifetime controlled 


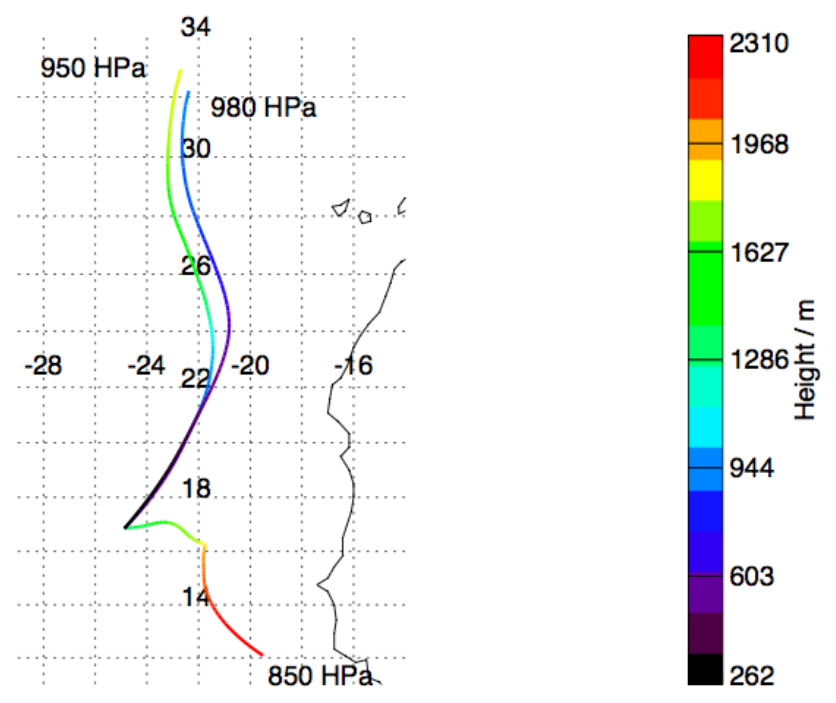

Fig. 15b. 3-D back trajectories arriving above the CVAO at 980 , 950 and $800 \mathrm{hPa}$, heights corresponding approximately to the three aircraft measurement heights.

by reaction with a few dominant species (notably $\mathrm{CH}_{4}$ and DMS). In the presence of significant remote marine $\mathrm{NO}_{\mathrm{x}}$ (largely unexplained, but possibly resulting from a combination of free-tropospheric entrainment and sea-air NO flux), night-time production of the nitrate radical, $\mathrm{NO}_{3}$, may be responsible for comparable contributions to DMS lifetime as daytime OH (Allan et al., 2000b). Such an oxidising environment will provide the backdrop for any perturbations resulting from halogen chemistry.

As the year of continuous observations of $\mathrm{BrO}$ and $\mathrm{IO}$ reported by Read et al. (2008) at CVAO demonstrate and, as discussed in more detail for the RHaMBLe intensive in Mahajan et al. (2009), there is unambiguous evidence for a substantial halogen cycling in the remote tropical Atlantic marine boundary layer. Such cycling is able to explain the geographically-widespread $\mathrm{O}_{3}$ loss reported in Read et al. (2008) and in the current work. It is unclear whether such XO levels are supported by the calculated sea-air flux of halocarbons and this is the subject of current investigation. Mahajan et al. (2009) uses a 1-dimensional modelling approach to investigate the vertical extent of halogen sources, cycling and impacts.

Predictions of the extent of halogen activation and quantification of the impacts requires a comprehensive characterisation of the marine aerosol. Allan et al. (2009) provides such a characterisation of the aerosol composition and properties measured on board the Discovery cruise D319 and at CVAO. A comparison of the measurements at both locations is reported along with a discussion of the aerosol impacts on and of halogen cycling and Müller et al. (2009a) presents a more detailed comparison of the size-resolved physical and chemical characteristics at CVAO.

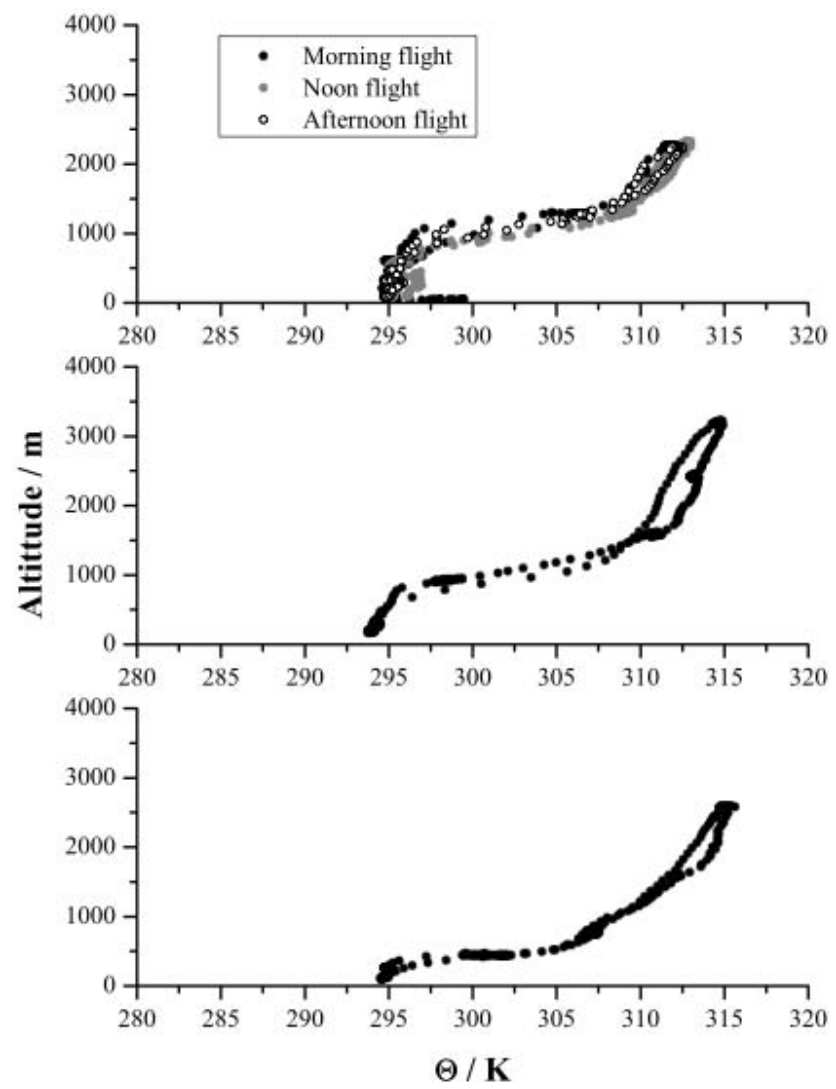

Fig. 16. Top panel shows tracks of 3 flights on 27 May at 10:00, 13:00 and 16:00 UTC showing altitude plotted against potential temperature. The middle and lower panels show altitude against potential temperature from flights on 26 and 29 May that intercepted the ship at positions $17^{\circ} 15^{\prime} 32^{\prime \prime} \mathrm{N}, 21^{\circ} 7^{\prime} 12^{\prime \prime} \mathrm{W}$ and $16^{\circ} 26^{\prime} 24^{\prime \prime} \mathrm{N}$, $20^{\circ} 21^{\prime} 36^{\prime \prime} \mathrm{W}$, respectively.

Whilst the direct impacts of reactive halogen chemistry on $\mathrm{HO}_{\mathrm{x}}$ through the cycle initiated by the reaction of $\mathrm{XO}$ and $\mathrm{HO}_{2}$ was previously postulated in a number of modelling studies, Bloss et al. (2005) used measurements of the $\mathrm{OH}$ and $\mathrm{HO}_{2}$ radicals at a coastal location to directly demonstrate these impacts for the first time. Such impacts on the oxidising budget had not been demonstrated in a remote marine location prior to the RHaMBLe project. Whalley et al. (2009) conducted budget studies, based on measured $\mathrm{OH}$ and $\mathrm{HO}_{2}$, using a constrained box model to investigate the magnitude of the impact of halogen at the measured $\mathrm{XO}$ concentrations on $\mathrm{HO}_{\mathrm{x}}$ and of the halogen-mediated impact on $\mathrm{CH}_{4}$ lifetime through enhanced $\mathrm{OH}$ concentration. A source of radicals entrained during the night-time would improve the agreement under certain assumptions of heterogeneous radical loss. Such a perturbation would not be inconsistent with the meteorological conditions reported herein.

Care should be taken not to categorise reactive halogen chemistry in all airmasses at CVAO as a clean remote marine phenomenon. The study of Lawler et al. (2009) clearly 
identified that elevated $\mathrm{Cl}_{2}$ concentrations were associated with airmasses containing high $\mathrm{HNO}_{3}$ levels. Model studies showed that such observations were consistent with $\mathrm{OH}$ attack on $\mathrm{HCl}$ and autocatalytic recycling and the concentrations of $\mathrm{Cl}$ would have substantially shortened $\mathrm{CH}_{4}$ and DMS lifetimes.

\section{Summary and conclusions}

An overview of the meteorological and chemical conditions experienced at the CVAO and the surrounding region during the RHaMBLe intensive study period in May and June 2007 has been presented. The CVAO was found to have always experienced air that arrives from the North East; however 8 day back trajectories suggest a range of air mass origins (European, Atlantic and North American continental). Concentrations of trace gases remained stable and fairly low during most of the intensive period, with the exception of an increase of around 30\% in CO, ethane and acetylene when the air was North American in origin. Even in this period, $\mathrm{NO}_{\mathrm{x}}$ levels remained stable and low ( $\left.<20 \mathrm{pptv}\right)$. Broad consistency these air mass classifications is observed in the time series of soluble gas and aerosol composition measurements, with additional identification of periods of slightly elevated dust concentrations consistent with the trajectories passing over the African continent. The CVAO has been shown to be representative of the wider North Atlantic marine boundary layer by both ship borne and aircraft measurements. Measurements of $\mathrm{NO}, \mathrm{O}_{3}$ and black carbon from the ship are consistent with measurements at the CVAO (and hence clean Northern Hemisphere marine background) and measurements of organic aerosol do not indicate any elevated amounts associated with clean marine air. East of $21^{\circ} \mathrm{W}$, levels of black carbon and NO start to increase, demonstrating much greater anthropogenic influence closer to the African coast. Ozone is also lower in this region; however this is possibly associated with the increased levels of halocarbons measured from the ship in this region. These increased halocarbon levels are believed to be associated with the nutrient rich waters of the Mauritanian upwelling. Bromide and chloride deficits in coarse mode aerosol at both CVAO and on D319 and the continuous abundance of reactive gaseous halogen species at CVAO indicate significant cycling of halogen cycling. Aircraft measurements have shown that the surface can be considered to be indicative of the entire depth of the boundary layer in the region. Flights carried out over the CVAO show identical behaviour in $\mathrm{O}_{3}$ and $\mathrm{CO}$ throughout the boundary layer, both in diurnal variability and absolute levels. Data taken above the inversion layer show similar diurnal behaviour in $\mathrm{O}_{3}$ and $\mathrm{CO}$, but both at lower mixing ratios. Analysis of ECMWF trajectories shows that air above the inversion originated from south of Cape Verde, possibly from within the ITCZ, consistent with the lower measured levels of $\mathrm{CO}$ and $\mathrm{O}_{3}$. ECMWF calculations on two days show apparently very different boundary layer depths and aircraft flights over the ship replicate this, giving confidence in the calculated boundary layer depth.

Acknowledgements. This work was supported by the NERC UK SOLAS programme under the "Reactive Halogens in the Marine Boundary Layer" (RHaMBLe) grant number NE/D006570/1. The aircraft measurements were made within the UK SOLAS "Chemical and Physical Structure Of The Lower Atmosphere Of The Tropical Eastern North Atlantic" project (NE/E01111X/1). Additional support for University of Manchester personnel was provided by the UK SOLAS "Aerosol Characterisation and Modelling in the Marine Environment" (ACMME, NE/E011454/1) grant and the NERC "Composition Of Microlayer Produced AeroSol" (COMPAS, NE/D005175/1) grant and results were presented through the "Integration \& synthesis of current research into the formation, evolution and roles of cloud condensation nuclei in the marine environment" (UK SOLAS CCN Knowledge Transfer) activity (NE/G000247/1). JDL, JDA, DEH, TI, LJW were all supported in part or in whole by UK National Centre for Atmospheric Sciences (NCAS) funding. ARB was funded under UK SOLAS grant number NE/C001931/1. ASM thanks the School of Chemistry, University of Leeds for his Ph.D. studentship. The University of New Hampshire and University of Virginia components were funded by the US National Science Foundation through award numbers ATM-0646865 and ATM-0646854, respectively; additional support was provided by the US Department of Energy's Office of Biological and Environmental Research Global Change Education Program. J. Maben (University of Virginia), R. Deegan (Mount Washington Observatory, Conway, NH, USA), and E. Crete (University of New Hampshire) assisted in sample collection and analysis. The University of California at Irvine participation was supported by NSF grant ATM-0614816. This is a contribution to SOLAS and the SOLAS/IGAC task Halogens in the Troposphere (HitT).

Edited by: W. T. Sturges

\section{References}

Alicke, B., Hebestreit, K., Stutz, J., and Platt, U.: Iodine oxide in the marine boundary layer, Nature, 397, 572-573, 1999.

Allan, B. J., McFiggans, G., Plane, J. M. C., and Coe, H.: Observations of iodine monoxide in the remote marine boundary layer, J. Geophys. Res., 105, 14361-14369, 2000.

Allan, B. J., McFiggans, G., Plane, J. M. C., Coe, H., and McFadyen, G. G.: The nitrate radical in the remote marine boundary layer, J. Geophys. Res., 105, 24191-24204, 2000.

Allan, B. J., Plane J. M. C., and McFiggans, G.: Observations of $\mathrm{OIO}$ in the remote marine boundary layer, Geophys. Res. Lett., 28, 1945-1948, 2001.

Allan, J. D., Topping, D. O., Good, N., Irwin, M., Flynn, M., Williams, P. I., Coe, H., Baker, A. R., Martino, M., Niedermeier, N., Wiedensohler, A., Lehmann, S., Müller, K., Herrmann, H., and McFiggans, G.: Composition and properties of atmospheric particles in the eastern Atlantic and impacts on gas phase uptake rates, Atmos. Chem. Phys., 9, 9299-9314, 2009, http://www.atmos-chem-phys.net/9/9299/2009/. 
Ayers, G. P., Gillett, R. W., Cainey, J. M., and Dick, A. L.: Chloride and bromide loss from sea-salt particles in southern ocean air, J. Atmos. Chem., 33, 299-319, 1999.

Ball, S. M., Hollingsworth, A. M., Humbles, J., Leblanc, C., Potin, P., and McFiggans, G.: Spectroscopic studies of molecular iodine emitted into the gas phase by seaweed, Atmos. Chem. Phys. Discuss., 9, 26329-26376, 2009, http://www.atmos-chem-phys-discuss.net/9/26329/2009/.

Behnke, W., Scheer, V., and Zetzsch, C.: Production of $\mathrm{BrNO}_{2}$, $\mathrm{Br}$ and $\mathrm{ClNO}_{2}$ from the reaction between sea spray aerosol and $\mathrm{N}_{2} \mathrm{O}_{5}$, J. Aerosol Sci., 25, S277-S278, 1994.

Birmili W., Stratmann, F., and Wiedensohler, A.: J. Aerosol Sci., 30(4), 549-553, 1999.

Bloss, W. J., Lee, J. D., Johnson, G. P., Sommariva, R., Heard, D. E., Saiz-Lopez, A., Plane, J. M. C., McFiggans, G., Coe, H., Flynn, M., Williams, P. I., Rickard, A., and Fleming, Z.: Impact of halogen monoxide chemistry upon boundary layer $\mathrm{OH}$ and $\mathrm{HO}_{2}$ concentrations at a coastal site, Geophys. Res. Lett., 32(6), L06814, doi:10.1029/2004GL022084, 2005.

Bonsang, B., Al Aabaour, A., and Sciare, J.: Diurnal variation of non-methane hydrocarbons in the subantarctic atmosphere, Environ. Chem., 5, 16-23, 2008.

Carpenter, L. J.: Iodine in the marine boundary layer, Chem. Rev., 103, 4953-4962, 2003.

Carpenter, L. J., Sturges, W. T., Penkett, S. A., Liss, P. S., Alicke, B., Hebestreit, K., and Platt, U.: Short-lived alkyl iodides and bromides at Mace Head, Ireland: links to biogenic sources and halogen oxide production, J. Geophys. Res., 104(D1), 1679-1689, 1999.

Carpenter, L. J., Malin, G., Küpper, F. C., and Liss, P. S.: Novel biogenic iodine-containing trihalomethanes and other short-lived halocarbons in the coastal East Atlantic, Global Biogeochem. Cy., 14, 1191-1204, 2000.

Carpenter, L. J., Jones, C. E., Dunk, R. M., Hornsby, K. E., and Woeltjen, J.: Air-sea fluxes of biogenic bromine from the tropical and North Atlantic Ocean, Atmos. Chem. Phys., 9, 1805-1816, 2009 , http://www.atmos-chem-phys.net/9/1805/2009/.

Chuck, A. L., Turner, S. M., and Liss, P. S.: Oceanic distributions and air-sea fluxes of biogenic halocarbons in the open ocean, J. Geophys. Res., 110, C10022, doi:10.1029/2004JC002741, 2005.

Cubison, M. J., Coe, H., and Gysel, M.: A modified hygroscopic tandem DMA and a data retrieval method based on optimal estimation, Aerosol Sci. Tech., 36(7), 846-865, 2005.

Currie, L. A.: Limits for qualitative detection and quantitative determination, Anal. Chem., 40, 586-593, 1968.

Edwards, G. D. and Monks, P. S.: Performance of a singlemonochromator diode array spectroradiometer for the determination of actinic flux and atmospheric photolysis frequencies, J. Geophys. Res. Atmos., 108(D16), 8546, doi:10.1029/2002JD002844, 2003.

Fickert, S., Adams, J. W., and Crowley, J. N.; Activation of $\mathrm{Br}_{2}$ and $\mathrm{BrCl}$ via uptake of $\mathrm{HOBr}$ onto aqueous salt solutions, J. Geophys. Res., 104, 23719-23727, 1999.

Finley, B. D. and Saltzman, E. S.: Observations of $\mathrm{Cl}_{2}, \mathrm{Br}_{2}$ and $\mathrm{I}_{2}$ in coastal marine air, J. Geophys. Res., 113, D21301, doi:10.1029/2008JD010269, 2008.

Fuentes, E., Coe, H., Green, D., and McFiggans, G.: Laboratorygenerated primary marine aerosol via bubble-bursting and atom- ization, Atmos. Meas. Tech., in press, 2010a.

Fuentes, E., Coe, H., Green, D., and McFiggans, G.: On the impacts of phytoplankton-derived organic matter on the properties of primary marine aerosol, Atmos. Chem. Phys. Discuss., in preparation, 2010b.

Gabriel, R., von Glasow, R., Sander, R., Andreae, M., and Crutzen, P. J.: Bromide content of sea-salt aerosol particles collected over the Indian Ocean during INDOEX 1999, J. Geophys. Res., 107, 8032, doi:10.1029/2001JD001133, 2002.

Garland, J. A. and Curtis, H.: Emission of iodine from the sea surface in the presence of ozone, J. Geophys. Res., 86(C4), 31833186, 1981.

Good, N., Topping, D. O., Allan, J. D., Flynn, M., Fuentes, E., Irwin, M., Williams, P. I., Coe, H., and McFiggans, G.: Consistency between parameterisations of aerosol hygroscopicity and CCN activity during the RHaMBLe Discovery cruise, Atmos. Chem. Phys. Discuss., 9, 22659-22692, 2009, http://www.atmos-chem-phys-discuss.net/9/22659/2009/.

Gysel, M., McFiggans, G. B., and Coe, H.: Inversion of tandem differential mobility analyser (TDMA) measurements, J. Aerosol Sci., 40(2), 134-151, 2009.

Haggerstone, A.-L., Carpenter, L. J., Carslaw, N., and McFiggans, G.: Improved model predictions of $\mathrm{HO}_{2}$ with gas to particle mass transfer rates calculated using aerosol number size distributions, J. Geophys. Res., 110, D04303, doi:10.1029/2004JD005282, 2005.

Hebestreit, K., Stutz, J., Rosen, D., Matveiv, V., Peleg, M., Luria, M., and Platt, U.: DOAS measurements of tropospheric bromine oxide in mid-latitudes, Science, 283, 55-57, 1999.

Herrmann, H., Brüggemann, E., Franck, U., Gnauk, T., Löschau, G., Müller, K., Plewka, A., and Spindler, G.: A source study of PM in Saxony by size-segregated characterisation, J. Atmos. Chem., 55, 103-130, 2006.

Hopkins, J. R., Lewis, A. C., and Read, K. A.: A two-column method for long-term monitoring of Non-methane hydrocarbons (NMHC) and oxygenated volatile organic compounds (o-VOCs), J. Environ. Monitor., 5, 8-13, 2002.

Keene, W. C., Talbot, R. W., Andreae, M. O., Beecher, K., Berresheim, H., Castro, M., Farmer, J. C., Galloway, J. N., Hoffmann, M. R., Li, S.-M., Maben, J. R., Munger, J. W., Norton, R. B., Pszenny, A. A. P., Puxbaum, H., Westberg, H., and Winiwarter, W.: An intercomparison of measurement systems for vapor and particulate phase concentrations of formic and acetic acids, J. Geophys. Res., 94, 6457-6471, 1989.

Keene, W. C., Maben, J. R., Pszenny, A. A. P., and Galloway, J. N.: Measurement technique for inorganic chlorine gases in the marine boundary layer, Environ. Sci. Technol., 27, 866-874, 1993.

Keene, W. C., Khalil, M. A. K., Erickson, D. J., McCulloch, A., Graedel, T. E., Lobert, J. M., Aucott, M. L., Gong, S.L., Harper, D. B., Kleiman, G., Midgley, P., Moore, R. M., Seuzaret, C., Sturges, W. T., Benkovitz, C. M., Koropalov, V., Barrie, L. A., and Li, Y.-F.: Composite global emissions of reactive chlorine from natural and anthropogenic sources: Reactive chlorine emissions inventory, J. Geophys. Res., 104, 8429-8440, 1999.

Keene, W. C., Stutz, J., Pszenny, A. A. P., Maben, J. R., Fischer, E. V., Smith, A. M., von Glasow, R., Pechtl, S., Sive, B. C., and Varner, R. K.: Inorganic chlorine and bromine in coastal New England air during summer, J. Geophys. Res., 112, D10S12, 
doi:10.1029/2006JD007689, 2007.

Keene, W. C., Long, M. S., Pszenny, A. A. P., Sander, R., Maben, J. R., Wall, A. J., O’Halloran, T. L., Kerkweg, A., Fischer, E. V., and Schrems, O.: Latitudinal variation in the multiphase chemical processing of inorganic halogens and related species over the eastern North and South Atlantic Oceans, Atmos. Chem. Phys., 9, 7361-7385, 2009, http://www.atmoschem-phys.net/9/7361/2009/.

Kozlova, E. A. and Manning, A. C.: Methodology and calibration for continuous measurements of biogeochemical trace gas and $\mathrm{O}_{2}$ concentrations from a 300-m tall tower in central Siberia, Atmos. Meas. Tech., 2, 205-220, 2009, http://www.atmos-meastech.net/2/205/2009/.

Langridge, J. M., Ball, S. M., Shillings, A. J. L., and Jones, R. L.: A broadband absorption spectrometer using light emitting diodes for ultrasensitive, in situ trace gas detection, Rev. Sci. Instrum., 79, 12, 10178-10188, 2008.

Lawler, M. J., Finley, B. D., Keene, W. C., Pszenny, A. A. P., Read, K. A., von Glasow, R., and Saltzman, E. S.: Pollutionenhanced reactive chlorine chemistry in the eastern tropical Atlantic boundary layer, Geophys. Res. Lett., 36, L08810, doi:10.1029/2008GL036666, 2009.

Lawrence, M. G., Jöckel, P., and von Kuhlmann, R.: What does the global mean $\mathrm{OH}$ concentration tell us?, Atmos. Chem. Phys., 1, 37-49, 2001, http://www.atmos-chem-phys.net/1/37/2001/.

Lee, J. D., Moller, S. J., Read, K. A., Lewis, A. C., Mendes L., and Carpenter, L. J.: Year round measurements of nitrogen oxides and ozone in the tropical North Atlantic marine boundary layer, J. Geophys. Res., 114(D21), D21302, doi:10.1029/2009JD011878, 2009.

Leser, H., Hönninger, G., and Platt, U.: MAX-DOAS measurements of $\mathrm{BrO}$ and $\mathrm{NO}_{2}$ in the marine boundary layer, Geophys. Res. Lett., 30(10), 1537, doi:10.1029/2002GL015811, 2003.

Lewis, A. C., McQuaid, J. B., Carslaw, N., and Pilling, M. J.: Diurnal cycles of short-lived tropospheric alkenes at a north Atlantic coastal site, Atmos. Environ., 33, 2417-2422, 1999.

Lowe, D., Topping, D., and McFiggans, G.: Modelling multiphase halogen chemistry in the remote marine boundary layer: investigation of the influence of aerosol size resolution on predicted gas- and condensed-phase chemistry, Atmos. Chem. Phys., 9, 4559-4573, 2009, http://www.atmos-chemphys.net/9/4559/2009/.

Maben, J. R., Keene, W. C., Pszenny, A. A. P., and Galloway, J. N.: Volatile inorganic chlorine in surface air over eastern North America, Geophys. Res. Lett., 22, 3513-3516, 1995.

Mahajan, A. S., Plane, J. M. C., Oetjen, H., Mendes, L., Saunders, R. W., Saiz-Lopez, A., Jones, C. E., Carpenter, L. J., and McFiggans, G. B.: Measurement and modelling of reactive halogen species over the tropical Atlantic Ocean, Atmos. Chem. Phys. Discuss., 9, 24281-24316, 2009, http://www.atmos-chem-physdiscuss.net/9/24281/2009/.

Martino, M., Mills, G. P., Woeltjen, J., and Liss, P. S.: A new source of volatile organoiodine compounds in surface seawater, Geophys. Res. Lett., 36, L01609, doi:10.1029/2008GL036334, 2009.

McFiggans, G., Plane, J. M. C., Allan, B. J., Carpenter, L. J., Coe, H., and O'Dowd, C.: A modeling study of iodine chemistry in the marine boundary layer, J. Geophys. Res. A., 105, 1437114385, 2000.

McFiggans, G., Cox, R. A., Mössinger, J. C., Allan, B. J., and
Plane, J. M. C.: Roles of iodine and nitrogen in the release of active chlorine from marine aerosols, J. Geophys. Res., 107, 4271, doi:10.1029/2001JD000383, 2002.

McFiggans, G., Bale, C. S. E., Ball, S. M., Beames, J. M., Bloss, W. J., Carpenter, L. J., Dorsey, J., Dunk, R., Flynn, M. J., Furneaux, K. L., Gallagher, M. W., Heard, D. E., Hollingsworth, A. M., Hornsby, K., Ingham, T., Jones, C. E., Jones, R. L., Kramer, L. J., Langridge, J. M., Leblanc, C., LeCrane, J.-P., Lee, J. D., Leigh, R. J., Longley, I., Mahajan, A. S., Monks, P. S., Oetjen, H., Orr-Ewing, A. J., Plane, J. M. C., Potin, P., Shillings, A. J. L., Thomas, F., von Glasow, R., Wada, R., Whalley, L. K., and Whitehead, J. D.: Iodine-mediated coastal particle formation: an overview of the Reactive Halogens in the Marine Boundary Layer (RHaMBLe) Roscoff coastal study, Atmos. Chem. Phys. Discuss., 9, 26421-26489, 2009, http://www.atmos-chem-physdiscuss.net/9/26421/2009/.

Müller, K., Lehmann, S., van Pinxteren, D., Gnauk, T., Niedermeier, N., Wiedensohler, A., and Herrmann, H.: Particle characterization at the Cape Verde atmospheric observatory during the 2007 RHaMBLe intensive, Atmos. Chem. Phys. Discuss., 9, 22739-22771, 2009, http://www.atmos-chem-physdiscuss.net/9/22739/2009/.

Müller, T., Schladitz, A., Kaaden, A., Ma, N., and Wiedensohler, A.: Spectral absorption coefficients and refractive index of Saharan mineral dust, Tellus, 61B(1), 79-95, 2009.

Newberg, J. T., Matthew, B. M., and Anastasio, C.: Chloride and bromide depletions in sea-salt particles over the northeastern Pacific Ocean, J. Geophys. Res., 110, D06209, doi:10.1029/2004JD005446, 2005.

O'Brien, L. M., Harris, N. R. P., Robinson, A. D., Gostlow, B., Warwick, N., Yang, X., and Pyle, J. A.: Bromocarbons in the tropical marine boundary layer at the Cape Verde Observatory, Meas. Model., 9, 4335-4379, 2009.

Pechtl, S., Lovejoy, E. R., Burkholder, J. B., and von Glasow, R.: Modeling the possible role of iodine oxides in atmospheric new particle formation, Atmos. Chem. Phys., 6, 505-523, 2006, http://www.atmos-chem-phys.net/6/505/2006/.

Peters, C., Pechtl, S., Stutz, J., Hebestreit, K., Hnninger, G., Heumann, K. G., Schwarz, A., Winterlik, J., and Platt, U.: Reactive and organic halogen species in three different European coastal environments, Atmos. Chem. Phys., 5, 3357-3375, 2005, http://www.atmos-chem-phys.net/5/3357/2005/.

Plane, J. M. C. and Saiz-Lopez, A.: UV-Visible Differential Optical Absorption Spectroscopy (DOAS) in: Analytical techniques for atmospheric measurement, edited by: Heard, D. E., WileyBlackwell, Oxford, 2006.

Pszenny, A. A. P., Moldanová, J., Keene, W. C., Sander, R., Maben, J. R., Martinez, M., Crutzen, P. J., Perner, D., and Prinn, R. G.: Halogen cycling and aerosol $\mathrm{pH}$ in the Hawaiian marine boundary layer, Atmos. Chem. Phys., 4, 147-168, 2004, http://www.atmos-chem-phys.net/4/147/2004/.

Quack, B., Atlas, E., Petrick, G., Stroud, V., Schauffler, S., and Wallace, D. W. R.: Oceanic bromoform sources for the tropical atmosphere, Geophys. Res. Lett., 31, L23S05, doi:10.1029/2004GL020597, 2004.

Quack, B., Atlas, E., Petrick, G., and Wallace, D. W. R.: Bromoform and dibromomethane above the Mauritanian upwelling: Atmospheric distributions and oceanic emissions, J. Geophys. Res., 112, D09312, doi:10.1029/2006jd007614, 2007. 
Rahn, K. A., Borys, R. D., and Duce, R. A.: Tropospheric halogen gases: Inorganic and organic components, Science, 192, 549550, 1976.

Ratte, M., Bujok, O., Spitzy, A., and Rudolph, J.: Photochemical alkene formation in seawater from dissolved organic carbon: Results from laboratory experiments, J. Geophys. Res., 103, 57075717, 1998.

Read, K. A., Mahajan, A. S., Carpenter, L. J., Evans, M. J., Faria, B. V. E., Heard, D. E., Hopkins, J. R., Lee, J. D., Moller, S. J., Lewis, A. C., Mendes, L., McQuaid, J. B., Oetjen, H., Saiz-Lopez, A., Pilling, M. J., and Plane, J. M. C.: Extensive halogen-mediated ozone destruction over the tropical Atlantic Ocean, Nature, 453, 1232-1235, 2008.

Read, K. A., Carpenter, L. J., Lee, J. D., Lewis, A. C., and Mendes, L.; Intraannual cycles of NMVOCs in the tropical troposphere and their use for interpreting seasonal variability in CO, J. Geophys. Res., 114(D21), D21303, doi:10.1029/2009JD011879, 2009.

Riemer, D. D., Milne, P. J., Zika, R. G., and Pos, W. H.: Photoproduction of nonmethane hydrocarbons (NMHCs) in seawater, Mar. Chem., 71, 177-198, 2000.

Saiz-Lopez, A. and Plane, J. M. C.: Novel iodine chemistry in the marine boundary layer, Geophys. Res. Lett., 31, L04112, doi:10.1029/2003GL019215, 2004a.

Saiz-Lopez, A., Plane, J. M. C., and Shillito, J. A., Bromine oxide in the mid-latitude marine boundary layer, Geophys. Res. Lett., 31, L03111, doi:10.1029/2003GL018956, 2004b.

Saiz-Lopez, A., Plane, J. M. C., Mahajan, A. S., Anderson, P. S., Bauguitte, S. J.-B., Jones, A. E., Roscoe, H. K., Salmon, R. A., Bloss, W. J., Lee, J. D., and Heard, D. E.: On the vertical distribution of boundary layer halogens over coastal Antarctica: implications for $\mathrm{O}_{3}, \mathrm{HO}_{\mathrm{x}}, \mathrm{NO}_{\mathrm{x}}$ and the $\mathrm{Hg}$ lifetime, Atmos. Chem. Phys., 8, 887-900, 2008, http://www.atmos-chemphys.net/8/887/2008/.

Sander, R., Keene, W. C., Pszenny, A. A. P., Arimoto, R., Ayers, G. P., Baboukas, E., Cainey, J. M., Crutzen, P. J., Duce, R. A., Hönninger, G., Huebert, B. J., Maenhaut, W., Mihalopoulos, N., Turekian, V. C., and Van Dingenen, R.: Inorganic bromine in the marine boundary layer: a critical review, Atmos. Chem. Phys., 3, 1301-1336, 2003, http://www.atmos-chemphys.net/3/1301/2003/.

Sander, R. and Crutzen, P. J.: Model study indicating halogen activation and ozone destruction in polluted air masses transported to the sea, J. Geophys. Res., 101, 9121-9138, 1996.

Sander, R., Rudich, Y., von Glasow, R., and Crutzen, P. J.: The role of $\mathrm{BrNO}_{3}$ in marine tropospheric chemistry: A model study, Geophys. Res. Lett., 26, 2857-2860, 1999.

Schmid, H., Laskus, L., Abraham, H. J., Baltensperger, U., Lavanchy, V., Bizjak, M., Burba, P., Cachier, H., Crow, D., Chow, J., Gnauk, T., Even, A., ten Brink, H. M., Giesen, K. P., Hitzenberger, R., Hueglin, C., Maenhaut, W., Pio, C., Carvalho, A., Putaud, J.-P., Toom-Sauntry, D., and Puxbaum, H.: Results of the "carbon conference" international aerosol carbon round robin test stage I, Atmos. Environ., 35, 2111-2121, 2001.

Simmonds, P. G., Derwent, R. G., Manning, A. J., Fraser, P. J., Krummel, P. B., O’Doherty, S., Prinn, R. G., Cunnold, D. M., Miller, B. R., Wang, H. J., Ryall, D. B., Porter, L. W., Weiss, R. F., and Salameh, P. K.: AGAGE observations of methyl bromide and methyl chloride at Mace Head, Ireland, and Cape
Grim, Tasmania, 1998-2001, J. Atmos. Chem., 47, 243-269, 2004.

Stutz, J., Hebestreit, K., Alicke, B., and Platt, U.: Chemistry of halogen oxides in the troposphere: Comparison of model calculations with recent field data, J. Atmos. Chem., 34, 65-85, 1999.

Toumi, R.: BrO as a Sink for Dimethylsulphide in the Marine Atmosphere, Geophys. Res. Lett., 21(2), 117-120, 1994.

Toyota, K., Takahashi, M., and Akimoto, H.: Modeling multiphase halogen chemistry in the marine boundary layer with size-segregated aerosol module: Implications for quasi-sizedependent approach, Geophys. Res. Lett., 28, 2899-2902, 2001.

Vogt, R., Crutzen, P., and Sander, R.: A mechanism for halogen release from sea-salt aerosol in the remote marine boundary layer, Nature, 383, 327-330, 1996.

Vogt, R., Sander, R., von Glasow, R., and Crutzen, P. J.: Iodine chemistry and its role in halogen activation and ozone loss in the marine boundary layer: A model study, J. Atmos. Chem., 32, 375-395, 1999.

von Glasow, R., Sander, R., Bott, A., and Crutzen, P. J.: Modeling halogen chemistry in the marine boundary layer. 1 . Cloud-free MBL, J. Geophys. Res., 107, 4341, doi:10.1029/2001JD000942, $2002 \mathrm{a}$.

von Glasow, R., Sander, R., Bott, A., and Crutzen, P. J.: Modeling halogen chemistry in the marine boundary layer. 2. Interactions with sulfur and cloud-covered MBL, J. Geophys. Res., 107, 4323, doi:10.1029/2001JD000943, 2002b.

von Glasow, R., von Kuhlmann, R., Lawrence, M. G., Platt, U., and Crutzen, P. J.: Impact of reactive bromine chemistry in the troposphere, Atmos. Chem. Phys., 4, 2481-2497, 2004, http://www.atmos-chem-phys.net/4/2481/2004/.

von Glasow, R. and Crutzen, P. J.: Tropospheric halogen chemistry, in: Treatise on Geochemistry Update 1, vol.4.02, edited by: Holland, H. D. and Turekian, K. K., Elsevier-Pergamon, Oxford, 167, 2007.

Whalley, L. K., Furneaux, K. L., Gravestock, T., Atkinson, H., Bale, C. S. E, Ingham, T., Bloss, W., and Heard, D. E.: Detection of iodine monoxide radicals in the marine boundary layer using laser induced fluorescence spectroscopy, J. Atmos. Chem., 58, 19-39, 2007.

Whalley, L. K., Furneaux, K. L., Goddard, A., Lee, J. D., Mahajan, A., Oetjen, H., Read, K. A., Kaaden, N., Carpenter, L. J., Lewis, A. C., Plane, J. M. C., Saltzman, E. S., Wiedensohler, A., and Heard, D. E.: The chemistry of $\mathrm{OH}$ and $\mathrm{HO}_{2}$ radicals in the boundary layer over the tropical Atlantic Ocean, Atmos. Chem. Phys. Discuss., 9, 15959-16009, 2009, http://www.atmos-chem-phys-discuss.net/9/15959/2009/.

Williams, J., Fischer, H., Wong, S., Crutzen, P. J., Scheele, M. P., and Lelieveld, J.: Near equatorial $\mathrm{CO}$ and $\mathrm{O}_{3}$ profiles over the Indian Ocean during the winter monsoon: $\mathrm{High}_{3}$ levels in the middle troposphere and interhemispheric exchange, J. Geophys. Res. Atmos., 107, 8007, doi:10.1029/2001JD001126, 2002.

Williams, P. I., McFiggans, G., and Gallagher, M. W.: Latitudinal aerosol size distribution variation in the Eastern Atlantic Ocean measured aboard the FS-Polarstern, Atmos. Chem. Phys., 7, 2563-2573, 2007, http://www.atmos-chem-phys.net/7/2563/2007/.

Zhou Z. and Mopper, K.: Carbonyl compounds in the lower marine troposphere over the Caribbean Sea and Bahamas, J. Geophys. Res., 98, 2385-2392, 1993. 